\title{
Equity Anomalies and Idiosyncratic Risk Around the World
}

\author{
Steve Fan* \\ University of Wisconsin - Whitewater, USA \\ Scott Opsal \\ University of Wisconsin - Whitewater, USA \\ Linda $\mathrm{Yu}$ \\ University of Wisconsin - Whitewater, USA
}

In this study, we examine how idiosyncratic risk is correlated with a wide array of anomalies, including asset growth, book-to-market, investment-to-assets, momentum, net stock issues, size, and total accruals, in international equity markets. We use zero-cost trading strategy and multifactor models to show that these anomalies produce significant abnormal returns. The abnormal returns vary dramatically among different countries and between developed and emerging countries. We provide strong evidence to support the limits of arbitrage theory across countries by documenting a positive correlation between idiosyncratic risk and abnormal return. It suggests that the existence of these well-known anomalies is due to idiosyncratic risk. In addition, we find that idiosyncratic risk has less impact on abnormal return in developed countries than emerging countries. Our results support the mispricing explanation of the existence of various anomalies across global markets. (JEL: G12, G15)

Keywords: anomalies, idiosyncratic risk, international equity markets, limits of arbitrage

Article history: Received: 3 October 2013, Received in final revised form: 26 August 2014, Accepted: 23 October 2014, Available online: 20 February 2015

\footnotetext{
* Corresponding author, Tel: 1-262-472-6943, Email: fanz@uww.edu. We received valuable comments and suggestions from three anonymous referees and editors Panayiotis $C$. Andreou and Panayiotis Theodossiou. All mistakes and errors remain to be our own responsibility.
}

(Multinational Finance Journal, 2015, vol. 19, no. 1, pp. 33-75)

(C) Multinational Finance Society, a nonprofit corporation. All rights reserved. DOI: $10.17578 / 19-1-2$ 


\section{Introduction}

Equity anomalies are empirical relations of future stock return with firm characteristics and the relations cannot be explained by classical asset pricing models such as the CAPM (Sharpe (1964), Lintner (1965)) and some highly influential factor models (such as Fama and French (1993), Carhart (1997), etc.). In other words, stock returns are predictable by various firm characteristics. Understanding anomalies has become increasingly important in asset allocation, security analysis, and other applications. Anomalies have been extensively studied, especially in the US market. Recently, researchers have extended anomaly studies to international markets. However, systematical investigation of some well-known anomalies across countries has not been conducted as extensive as in the US. In this study, we examine a number of anomalies across 43 countries from 1989 to 2009. The list of anomalies includes asset growth (AG), book-to-market value (BM), investment-to-assets (IA), short-term prior returns (momentum) $(M O M)$, net stock issues (NSI), size, and total accruals (TA). Since the scope of studies in anomalies has been massive, we focus on two main objectives to make our study manageable. First, we identify whether these anomalies exist internationally. Second, we investigate if the anomalies are correlated with idiosyncratic risk around the world.

To examine if the well-known anomalies exist internationally, we apply the common zero-cost portfolio approach to test if abnormal return can be realized for these anomalies. We divide all stocks in each country into quintiles based on the ranking of each anomaly variable in an ascending order (from the most overvalued to the most undervalued). We calculate both equal- and value-weighted monthly abnormal returns by longing the stocks in the fifth quintile and shorting the stocks in the first quintile every month. ${ }^{1}$ Our results show that the zero-cost strategy produces significant monthly abnormal returns for $\mathrm{BM}, M O M$, and size in most of the 43 countries. ${ }^{2}$ Significant abnormal monthly returns from AG, IA, NSI, and TA exist in some of the countries. ${ }^{3}$ When we group countries into developed and emerging countries, we find that developed countries exhibit higher abnormal returns for $\mathrm{AG}, M O M$, and

1. We report equal-weighted returns throughout this study. Value-weighted returns have similar but less significant results.

2. 26,23 , and 20 out of the 43 countries have significant average abnormal returns for $\mathrm{BM}, M O M$, and size at $5 \%$ level, respectively.

3. $12,8,12$, and 6 out of the 43 countries have significant average abnormal returns for AG, IA, NSI, and TA at 5\% level, respectively. 
NSI, while emerging countries have higher returns for BM, IA, and size. Abnormal returns associated with TA do not show significant difference between developed and emerging countries.

To study if these abnormal returns can be explained by some well-known risk factors, we apply the Fama-French three-factor model plus the momentum factor (Fama and French (1992, 1993), Carhart (1997)) and a newly developed alternative three-factor model to examine risk-adjusted returns (i.e. the a's). We acknowledge that a large number of studies exist on Fama-French style factor models in the literature (Pastor and Stambaugh (2003), Hoberg and Welch (2009), among others). Most of these studies offer convincing evidence that the proposed factor(s) has additional power to explain the variation in stock returns. In a recent study, Chen, Novy-Marx, and Zhang (2010) motivate an alternative three-factor model from q-theory and show that the new three-factor model is able to explain many return patterns in the US market that the Fama-French model is unable to explain. Because of its superior performance in explaining many anomalies, this alternative model has attracted a lot of attentions and has been applied in several published studies (Lipson, Mortal, and Schill (2012), Walkshausl and Lobe (2011), among others) since its introduction.

When applying factor models in a global context, a natural question is whether securities are priced locally or globally (Karolyi and Stulz, (2003)). Griffin (2002) examines country-specific and global versions of the Fama-French model. The author finds that the domestic factor model explains much more time-series variation in returns and generally has lower pricing errors than the global version. In a recent study, Hou, Karolyi, and Kho (2011) also find that local and international versions ${ }^{4}$ of their multifactor models have lower pricing errors than the global version, and it is particularly true for emerging markets. Based on the findings from these studies, we apply the domestic version for both the Fama-French and the alternative model in this paper.

Our results indicate that most of the significant abnormal returns from zero-cost strategies still exist after controlling for the risk factors. In other words, neither the Fama-French nor the alternative three-factor model can fully explain anomalies in international equity markets. We do not find the alternative model outperforms the Fama-French model in driving away anomalies in international markets. Our results are consistent with the study by Walkshausl and Lobe (2011), who compare the performance of the alternative model with the Fama- French model in countries beyond US.

Many studies have provided various explanations of the existence of

4. The international version includes both domestic and foreign factors. 
anomalies. The existence of anomalies is usually due to either market inefficiency (mispricing) or inadequacies in underlying asset-pricing models. In this study, we do not attempt to address the inadequacy of existing asset-pricing models or seek additional risk factors. We focus on the test of mispricing explanation by examining the impact of idiosyncratic risk on stock abnormal return. In the traditional mean variance analysis, only the market risk should be priced in equilibrium as predicted in the CAPM model. Any idiosyncratic risk is completely eliminated through diversification. However, CAPM holds only when investors are willing and able to hold a combination of the market portfolio and risk free asset. In practice, many investors are not able to hold such a portfolio due to various constraints, such as transaction costs, incomplete information, taxes, liquidity requirements, etc. It is also common that institutional investors often deliberately structure their portfolios to generate considerable idiosyncratic risk to obtain excess returns.

As Malkiel and $\mathrm{Xu}$ (2006) point out, the relative supply of the stocks that constrained investors are unable to hold is high, so the price of those stocks must be relatively low. Therefore, an idiosyncratic risk premium can be rationalized for such "unbalanced supply". In addition, if the constrained investors are unable to hold all securities, the "available market portfolio" for unconstrained investors will automatically become less diversified because it is the total holdings from the two groups of investors that make up the whole market (Malkiel and Xu (2006)). The risk premium of the "available market portfolio" tends to be higher than the actual market portfolio in the traditional CAPM model. Portions of the systematic risk would be considered as idiosyncratic risk relative to the actual market portfolio. Therefore, it would be priced in the market.

The idiosyncratic risk premium can also be rationalized under a multifactor model setting. The multifactor models of Merton (1973) and Ross (1976) show that risk-averse investors want to hedge against changes in volatility since volatility positively impact future expected market return. Chen (2002) develops a model under a heteroskedastic environment which allows for both time-varying covariance and stochastic market volatility. His study shows risk-averse investors also want to hedge against changes in future market volatility directly. The idiosyncratic risk may also arise if the market is segmented. For instance, Errunza and Losq (1985) conduct a theoretical and empirical investigation of the pricing implication due to market segmentation in international capital markets. They show the segmentation leads to 
"super" risk premiums due to the restriction on foreign ownership for some assets but not others. The segmentation could also link to the clientele effects in the investment decisions made by different groups of investors. Heston, Rouwenhorst, and Wessels (1995) indicate that large capitalization stocks are more integrated into the world market than small cap stocks. In practice, institutional investors often hold large, more diversified portfolios and more likely invest on large and growth stocks, while individual investors usually hold small cap and less diversified portfolios due to the limited investment capital. The difference in the holdings can persist in the long run, and the force of normal arbitrage is not sufficient to drive it away. Miffre, Brooks, and $\mathrm{Li}$ (2013) conduct an investigation to link the idiosyncratic risk with diversification more directly. Their results show the additional return for bearing the idiosyncratic risk is inversely related to the number of stocks in a portfolio (i.e. the level of diversification).

Shleifer and Vishny (1997) and Pontiff $(1996,2006)$ argue that idiosyncratic risk represents a significant cost for risk-averse arbitrageurs. Due to the high cost (i.e. the limits of arbitrage); equity anomalies are not driven away by rational investors. If idiosyncratic risk does limit arbitrageurs from offsetting the choices of irrational investors, abnormal returns will be greater among high idiosyncratic risk stocks (Ali, Hwang, and Trombley (2003), Mendenhall (2004), Mashruwala, Rajgopal, and Shevlin (2006), among others.). In other words, idiosyncratic risk should be positively correlated with abnormal return. We test this hypothesis across countries in this study.

There is considerable controversy over the empirical relation between idiosyncratic risk and expected return. Some studies (Bali et al. (2005), Huang et al. (2010), among others) suggest idiosyncratic risk is not priced. In other studies, both negative (Ang, et al. (2006, 2009), Guo and Savickas (2010)) and positive relations (Goyal and Santa-Clara (2003), Diavatopoulos, Doran, and Peterson (2008), Malkiel and Xu (2006), Fu (2009)) are documented. In a recent study, Fu (2009) demonstrates that the commonly used ordinary least square (OLS) method may not be appropriate to calculate idiosyncratic risk since idiosyncratic volatility does not follow a random walk. The author uses an exponential generalized autoregressive conditional heteroskedasticity (EGARCH) model to capture the time-variation of expected idiosyncratic risk. Using this approach, a strong positive relation between expected idiosyncratic volatility and returns is documented in the US market. We adopt the EGARCH model in this study.

Our results show that idiosyncratic risk exhibits a significant 
difference across countries. It varies from 0.074 (Luxembourg) to 0.312 (Portugal). The average idiosyncratic risk in developed countries is smaller than emerging countries $(0.130$ vs. 0.142$)$. To examine the relationship between idiosyncratic risk and abnormal returns, we form $5 \times 5$ portfolios based on interactions of quintiles of conditional idiosyncratic risk and quintiles of individual anomaly in each country. We calculate abnormal returns at each idiosyncratic risk quintile by shorting stocks in the first anomaly quintile and longing stocks in the fifth anomaly quintile. We find that abnormal returns for high-idiosyncratic-risk stocks are always higher than lowidiosyncratic-risk stocks in every anomaly. It suggests that idiosyncratic risk is positively correlated with abnormal return. We also find that abnormal returns become insignificant in low-idiosyncratic-risk stocks for most of the anomalies. These findings are present in both developed and emerging countries. We also observe that for the same level of idiosyncratic risk, developed countries usually have a lower abnormal return than emerging countries for all anomalies studied in this paper. The results demonstrate that idiosyncratic risk is an important factor that limits arbitrage opportunities in international equity markets.

To make sure that the positive correlation is not due to choice of testing methods and other country level characteristics, we further conduct regression analysis. Monthly risk adjusted abnormal return of the zero-cost portfolio (i.e. a's from the Fama-French model) is used as the dependent variable. Idiosyncratic risk of a zero-cost portfolio is the main independent variable. We define idiosyncratic risk of a zero-cost portfolio as the value-weighted average idiosyncratic risk of stocks with long position minus the value-weighted average idiosyncratic risk of stocks with short position. We control for country level variables that measure economic and financial development, economic growth, economic and financial integration, financial disclosure environment, and corporate governance. We conduct panel regression analysis with standard errors clustered by country and year (Petersen (2009)). Our results confirm that there is a strong positive correlation between abnormal returns and idiosyncratic risk at portfolio level even after controlling for these country-level characteristics.

Mispricing hypothesis suggests that better governance, stronger investor protection, higher accounting quality, and higher market efficiency would limit opportunities for mispricing (Barberis and Thaler, (2003)). Therefore, we would expect that developed countries have lower abnormal returns than emerging countries in general. Furthermore, if idiosyncratic risk is indeed a significant factor 
producing anomalies, the same idiosyncratic risk would have less impact on abnormal return in developed countries. To test these hypotheses, a dummy variable is used to distinguish the abnormal return differences between developed and emerging countries. An interaction term of the dummy variable and idiosyncratic risk is used to differentiate the difference of idiosyncratic risk impact on abnormal returns between developed and emerging countries. Our results do not show strong support for the hypothesis that developed countries have lower abnormal returns. Although we document a negative coefficient for the dummy variable for most of the anomalies (expect for AG), only size is significant. However, our results show that the interaction term for most anomalies is negative and significant. It suggests that the same level of idiosyncratic risk has less impact on abnormal returns in developed countries. Overall, our results provide evidence to support the mispricing explanation.

This paper contributes to the growing literature that examines anomalies in several ways. First, we document a list of anomaly variables across countries in a systematic way for a long time period. Although these anomalies are well known for the US market, they are less explored in other countries. Second, we provide strong evidence that idiosyncratic risk contributes to the existence of these anomalies. Most current studies on this topic focus on the US market. We provide results that support the limits of arbitrage theory in countries outside the US and for more anomalies as well. Finally, we provide new evidence to support the mispricing explanation by showing that the impact of idiosyncratic risk on abnormal returns in developed countries is less than the impact in emerging countries.

The rest of this paper proceeds as follows: Section II describes data and explains how we construct each anomaly; Section III uses the zero-cost trading strategy to analyze abnormal returns; Section IV uses the factor models to study risk-adjusted abnormal returns; Section V investigates correlations between idiosyncratic risk and anomalies using both portfolio approaches and regression analysis; and Section VI concludes.

\section{Data and Anomaly Variable Construction}

\section{A. Data}

We collect stock monthly returns, stock prices, and number of shares 
outstanding from 1989 through 2009 for firms in 43 countries from Thomson Financial's DataStream. All variables are expressed in US dollar. We restrict our analysis to common-ordinary stocks trading in the companies' home markets. To identify common-ordinary stocks, we apply Griffin, Kelly, and Nardari (2010) multi-stage screening method to eliminate preferred stocks, warrants, units or investment trusts, duplicates, GDRs or cross-listings, and other non- common equity from the sample. ${ }^{5}$ Detailed description of the filtering process can be found in Griffin, Kelly, and Nardari (2010). As pointed out by Ince and Porter (2006) and Karolyi, Lee, and Van Dirk (2012), DataStream data have many errors. To eliminate the impact of these reporting errors, we follow the screening criteria suggested by Ince and Porter (2006). These criteria have been used by many international studies using DataStream data (Karolyi et al., 2012, Hou et al., 2011, among others). First, we only include active stocks in our analysis. Unlike CRSP data, DataStream repeats the last valid data point for the delisted firms. To exclude the dead stocks, we eliminate the observations with consecutive zero returns at the end of sample period. Second, we apply several screening procedures for monthly returns, as suggested by Ince and Porter (2006) and others. Any return above 300\% that is reversed within one month is treated as missing. In order to exclude remaining return outliers, we treat the monthly returns as missing if they are below $0.1 \%$ and over $99.9 \%$ percentile in each country. Hou, et al. (2011) show that DataStream produces average monthly returns that are close to the results using CRSP/COMPUSTAT data after applying above screening criteria. DeMoor and Sercu (2005) also show that their results are very similar for different sets of assets whether using CRSP/Compustat data or the US data from the DataStream.

We collect a number of country level variables that are likely to affect equity returns. These country-level variables are grouped into five categories that capture various country characteristics:

Economic and Financial Development.

Economic Growth.

Economic and Financial Integration.

Financial Disclosure Environment.

Corporate Governance Environment.

5. We thank Griffin, Kelly, and Nardari for making their program available. 
Details of these variables can be found in appendix A.

\section{B. Construction of anomaly variables}

A wide range of firm-level accounting data is collected from WorldScope to form various anomalies. We study seven anomaly variables that have been accepted by academics. ${ }^{6}$ Some anomalies, such as momentum and total accruals, have been found to be persistent after being discovered, while others, such as size, disappear. In this study, we do not intend to address if an anomaly is persistent. We simply test whether we can earn abnormal returns if we hold portfolios formed on the zero-cost trading strategy using these anomalies for the time period 1989-2009.

In a recent study, Tang, Wu, and Zhang (2013) examine a long list of anomalies for the US equity market. We follow the same methods as in their study to construct seven anomalies. The construction details of each anomaly are as follows:

Asset Growth (AG). Firms with high asset growth earn lower average returns than firms with low asset growth (Cooper, Gulen, and Schill (2008)). We measure asset growth as total assets (WorldScope 07230) at the fiscal year-end minus lagged total assets divided by lagged total assets.

Book-to-Market (BM). Many studies (Fama and French (1993, 1994), among others) show that high BM stocks earn higher average returns than low BM stocks. BM is book value of equity (WorldScope 07220) at the fiscal year-end divided by market value of equity (WorldScope 08001).

Investment-to-Assets (IA). High IA firms earn lower average returns than low IA firms (Lyandres, Sun, and Zhang (2008), Chen, et al. (2010)). We measure IA as the annual change in gross property, plant, and equipment (WorldScope 02301) plus the annual change in inventory (WorldScope 18196) divided by lagged total assets.

Short-term prior returns (Momentum) (MOM). Stocks that perform well in recent months continue to earn higher average returns in future months than stocks that perform poorly (Jegadeesh and Titman (1993), among others). Following Jegadeesh and Titman (1993), we construct momentum portfolios using the " $6 / 1 / 6$ " convention. At the beginning of

6. Please see Schwert (2006) for a summary of well-known anomalies. Richardson, Tuna, and Wysocki (2010) also have a comprehensive survey on accounting anomalies and fundamental analysis. 
each month $\mathrm{t}$, we compute $M O M$ as the past 6-month cumulative returns from month $t-2$ to $t-7$, skipping month $t-1$.

Net Stock Issues (NSI). Firms that issue new equity underperform firms with similar characteristics (Fama and French (2008)). NSI measures the annual change in the logarithm of the number of shares outstanding (Fama and French (2008)). NSI is calculated as the natural $\log$ of the ratio of the number of shares outstanding at the fiscal year-end divided by the number of shares outstanding at previous fiscal year-end. NSI can be positive or negative.

Size. Small firms earn higher average returns than big firms (Banz (1981), Fama French (1992, 1993), Griffin (2002)). Size is measured as total market capitalization (WorldScope 07210).

Total Accruals (TA). High TA firms earn lower average returns than low TA firms (Sloan (1996), Pincus, Rajgopal, and Venkatachalam (2007)). Following Pincus, Rajgopal, and Venkatachalam (2007), we measure TA as net income (WorldScope 01651) minus operating cash flows (WorldScope 04860) scaled by lagged total assets.

\section{Zero-cost Portfolios and Abnormal Returns}

We use zero-cost strategy to construct portfolios based on computed anomaly variables. For anomaly AG, BM, IA, NSI, size, and TA, in June of each year $t$, we rank all stocks in each country in an ascending order (from the most overvalued to the most undervalued). ${ }^{7}$ We then divide stocks into quintiles based on the ranking in calendar year $t-1$ for each anomaly. We take long position for stocks in the fifth quintile (the most undervalued, such as small firms) and short position for stocks in the first quintile (the most overvalued, such as large firms). Monthly equal-weighted portfolio returns are calculated from July of year $t$ to June of year $t+1$, and the portfolios are re-balanced in June of $t+1$.

For anomaly $M O M$, we follow a conventional construction method; all stocks in each country are ranked in ascending order based on $M O M$ variable at the beginning of each month. Stocks are grouped into quintiles based on the ranking. Stocks in the first quintile are assigned to the loser portfolio and those in the fifth quintile are assigned to the winner portfolio. The equal-weighted portfolios are held for 6 months. An overlapping portfolio is constructed to increase testing power (Jegadeesh and Titman (1993)). A zero-cost portfolio is constructed as

7. For example, when we use size anomaly to rank stocks, first quintile consists the largest firms (overvalued) and fifth quintile consists the smallest firms (undervalued). 


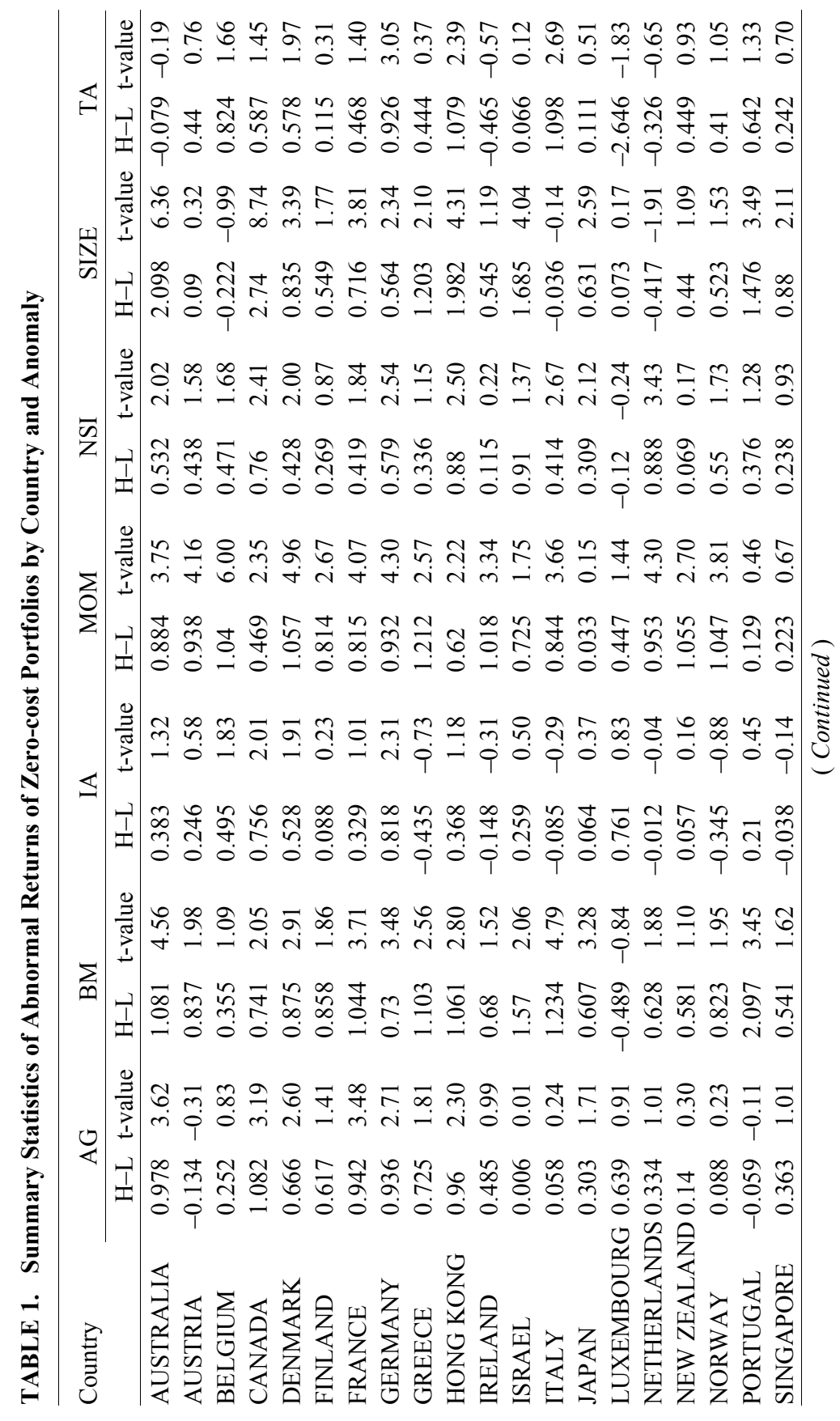




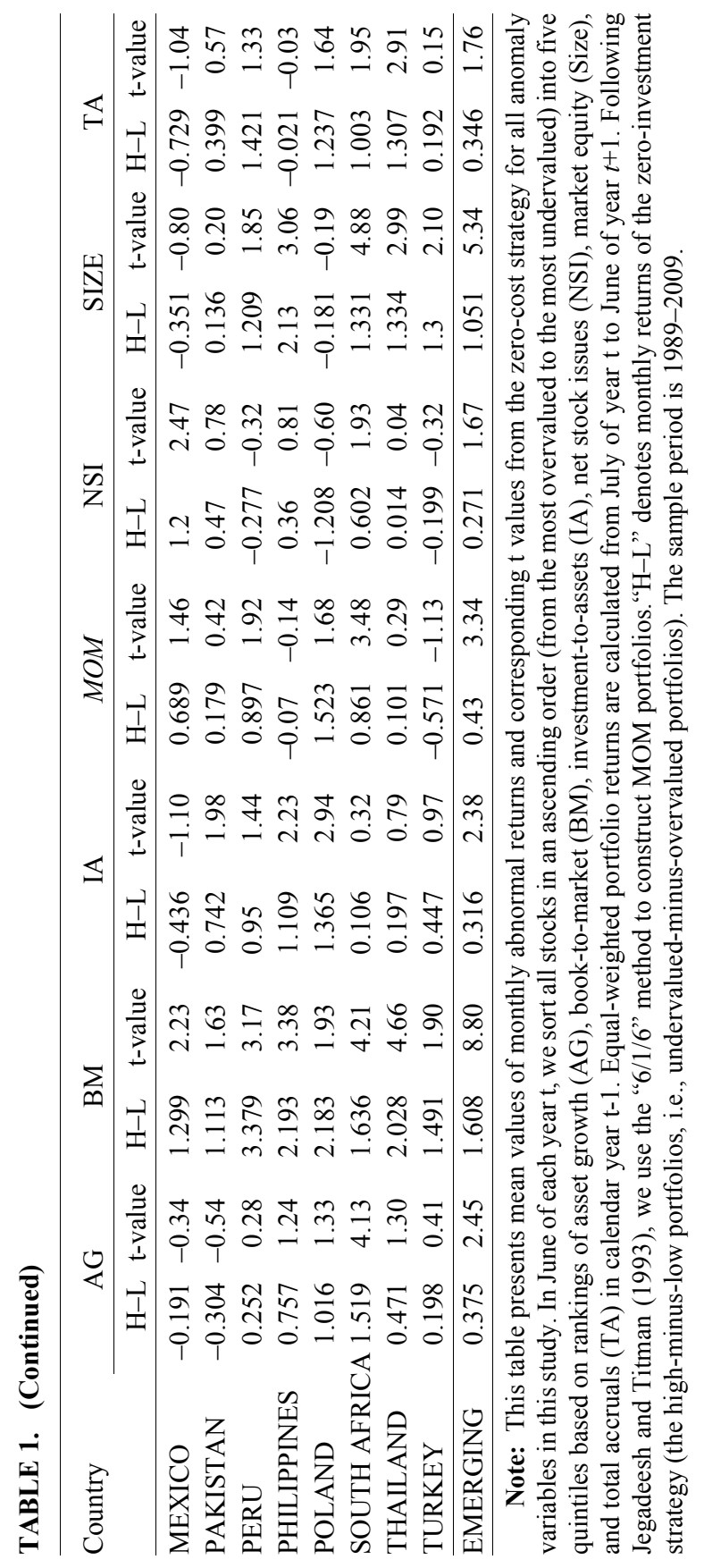


winner-minus-loser portfolio.

Table 1 reports average monthly returns of the zero-cost portfolios and corresponding $t$ values for the entire time period of this study. We report average monthly returns for each individual country and the pooled average for developed and emerging countries. As shown in table 1, our results are consistent with existing evidence in the literature. For instance, firms with a lower AG, higher BM, lower IA, lower NSI, higher $M O M$, smaller size, and lower TA, earn higher returns. In addition, significant abnormal returns associated with $\mathrm{BM}, M O M$, and size are present in more countries compared to abnormal returns associated with other anomalies.

The magnitude of monthly abnormal returns varies dramatically across countries. Ab- normal returns vary from $0.30 \%$ (Japan) to $1.52 \%$ (South Africa) for AG, $0.53 \%$ (Spain) to $3.38 \%$ (Hungary) for BM, $0.13 \%$ (US) to $1.22 \%$ (India) for IA, $0.47 \%$ (Canada) to $1.52 \%$ (Poland) for MOM, $0.31 \%$ (Japan) to $2.69 \%$ (US) for NSI, $0.55 \%$ (Finland) to $3.10 \%$ (Hun- gary) for Size, and $0.58 \%$ (Denmark) to $2.16 \%$ (US) for TA. We also report average abnormal returns for developed and emerging countries. We find that developed countries have higher abnormal returns for AG, $M O M$, and NSI, while emerging countries have higher abnormal returns for BM, IA, and Size. Abnormal returns for TA do not show much difference between developed and emerging countries.

\section{Risk-adjusted Returns of Zero-cost Portfolios}

To test if these anomalies can be explained by risk factors, we estimate risk-adjusted returns using two factor models: (1) Fama-French four-factor model $^{8}$, and (2) a new alter- native three-factor model (Chen, et al., 2010). We investigate the a of each factor model for every anomaly. If the abnormal returns of zero-cost portfolios can be explained by risk factors, we should observe insignificant $\alpha$ 's.

\section{A. The Fama-French factor model}

Fama and French $(1992,1993)$ propose a three-factor model to improve CAPM pricing errors by adding size and book-to-market risk factors.

8. The Fama-French four-factor model refers to the Fama-French three-factor model plus the momentum factor. 
Carhart (1997) demonstrates that a momentum factor (Jegadeesh and Titman (1993)) should also be included in the model. The four-factor model is given by

$$
R_{i t}=\alpha_{i}+\beta_{0 i} R M_{t}+\beta_{1 i} S M B_{t}+\beta_{2 i} H M L_{t}+\beta_{1 i} M O M_{t}+\varepsilon_{i t}
$$

where $R_{i t}$ is stock return in US dollar in excess of the one-month US Treasury bill rate in month $t$. We construct the size $(S M B)$ and book-to-market $(H M L)$ factor in the same way as Fama and French (1992, 1993). We first construct $2 \times 3$ size/book-to-market benchmark portfolios. The size breakpoint is the median market equity in each country. The book-to-market breakpoints are the 30th and 70th percentiles of $H M L$ in each country. $S M B$ is the average return of the small-capitalization portfolios minus the average return of the large-capitalization portfolios; $H M L$ is the difference in average returns between the portfolios with high book-to-market stocks and the portfolios with low book-to-market stocks. We construct monthly risk factors for each country, separately. Domestic market monthly return $R M$ is computed using value-weighted average returns in US dollar of all stocks in each country.

To compute monthly momentum factor, six portfolios are formed on the intersections of two portfolios formed on size and three portfolios formed on prior six month (escaping the most recent month) cumulative returns. We use the median market capitalization at month $t-1$ in each country as breakpoint for the size portfolios. We use the 30th and 70th percentiles of prior cumulative returns as breakpoints for the prior return portfolios. We classify the bottom $30 \%$ as losers portfolio, the middle $40 \%$ as medium, and the top $30 \%$ as winners portfolio. MOM factor for month $t$ is computed as follows:

$$
M O M=\frac{\text { SmallWinners }+ \text { Big Winners }- \text { Small Losers }- \text { Big Losers }}{2}
$$

We report monthly averages and $t$ values of the $S M B, H M L$, and $M O M$ for each country in table 2 .

\section{$B$. The alternative three-factor model}

Recently, evidence has shown that even the highly influential 


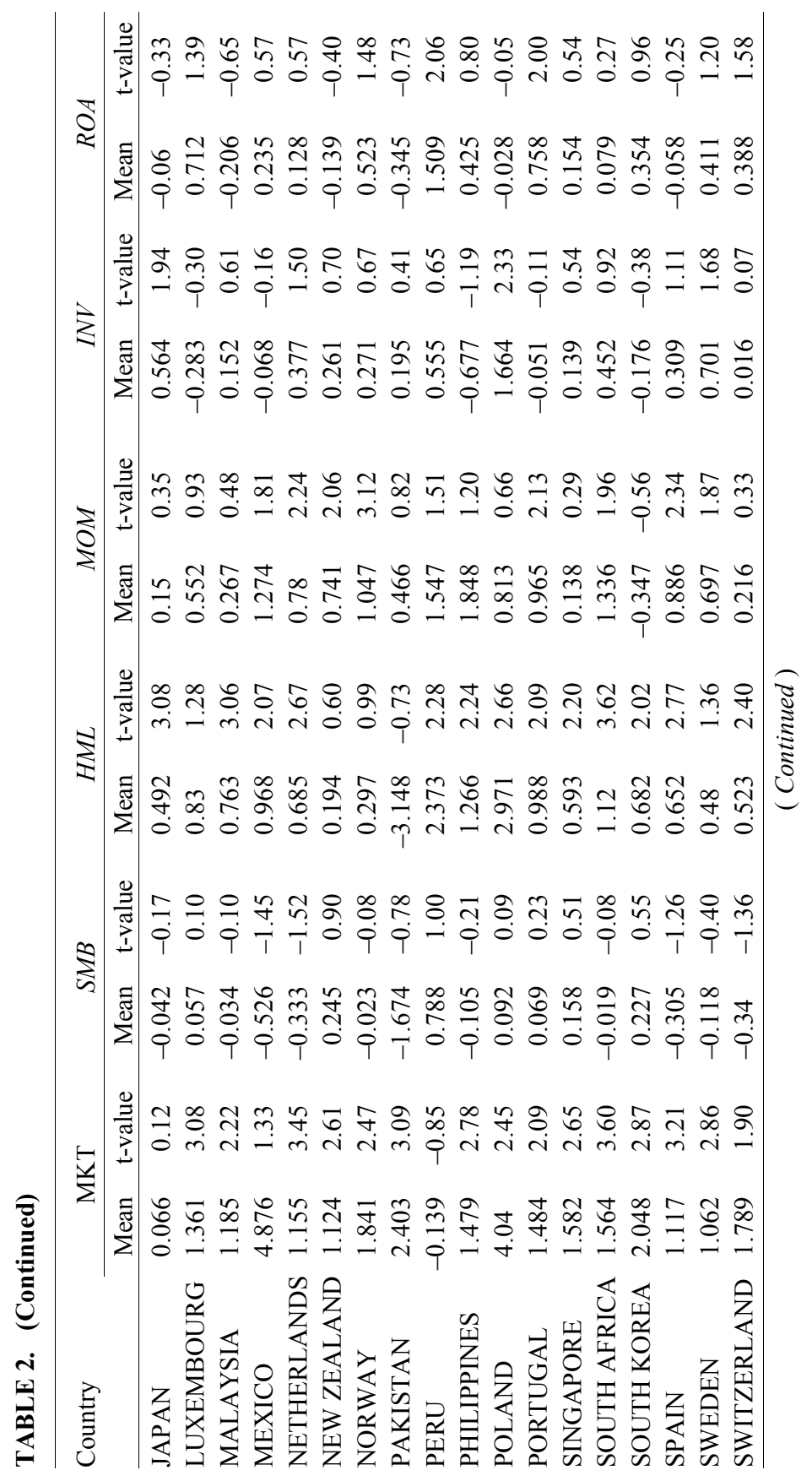




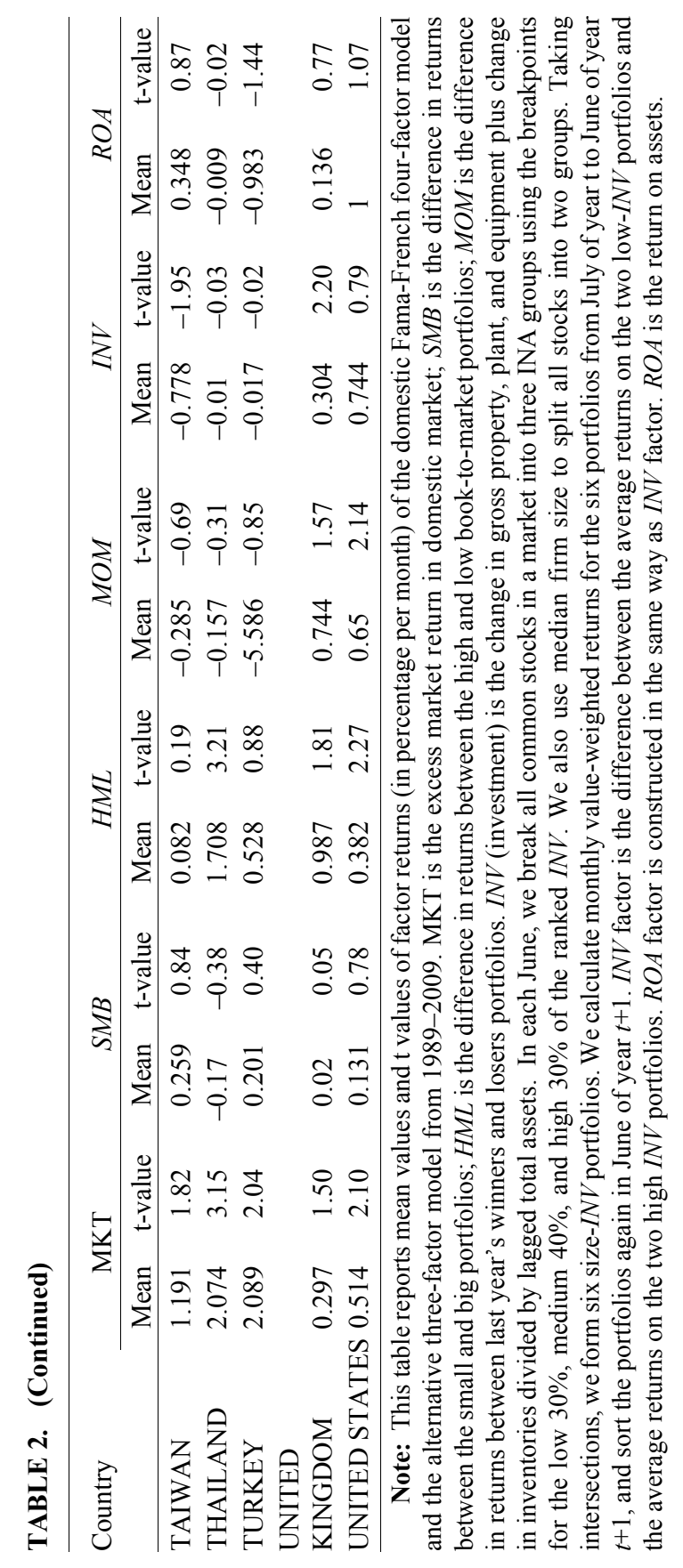


Fama-French model cannot explain many cross-sectional return patterns. ${ }^{9}$ Chen, et al. (2010) develop a three-factor model based on the q-theory. They show that their alternative model can explain a much wider range of the documented anomalies that cannot be explained by the Fama-French model in the US equity market. Because of its superior performance in the US market, we apply this model as a robustness check. The alternative three-factor model is given by

$$
R_{i t}=\alpha_{i}+\beta_{0 i} R M_{t}+\beta_{1 i} r_{I N V, t}+\beta_{2 i} r_{R O A, t}+\varepsilon_{i t}
$$

where $R_{i t}$ is the excess return computed in US dollar. $r_{I N V}$ is the low-minus-high INA (investment) factor and $r_{R O A}$ is the high-minus-low $R O A$ factor. We construct the investment factor, $r_{I N V}$, from two-by-three portfolios sorted on size and IA in a similar way as in Fama and French $(1992,1993)$. In June of each year $t$, we break all stocks in a country into three IA groups (breakpoints are low $30 \%$, medium $40 \%$, and high $30 \%$ ). The median market equity is used to split all stocks into two groups. Monthly value-weighted returns on the six portfolios are computed from July of year $t$ to June of $t+1$. Portfolios are re-balanced in June of year $t+1$. The INA factor is the difference between the average return of the two low-IA portfolios and the average return of the two high-IA portfolios in each month.

$$
r_{I N V}=\frac{\text { Small Low }+ \text { Big Low }- \text { Small High }- \text { Big High }}{2}
$$

The $R O A$ factor, $r_{R O A}$, is formed in the same way as $r_{I N V}$ except that we use $R O A$ variable instead of IA variable. $R O A$ factor is the monthly difference between the average return on the two high-ROA portfolios and the average return on the two low-ROA portfolios.

$$
r_{I N V}=\frac{\text { Small High }+ \text { Big High }- \text { Small Low }- \text { Big Low }}{2}
$$

Table 2 reports monthly averages and $t$ values of the IA and $R O A$ factors for each country.

9. Examples include Chan, et al., (1996), Fama and French (1996, 2008), Griffin and Lemmon (2002), Daniel and Titman (2006), Cooper, et al., (2008), among others. 


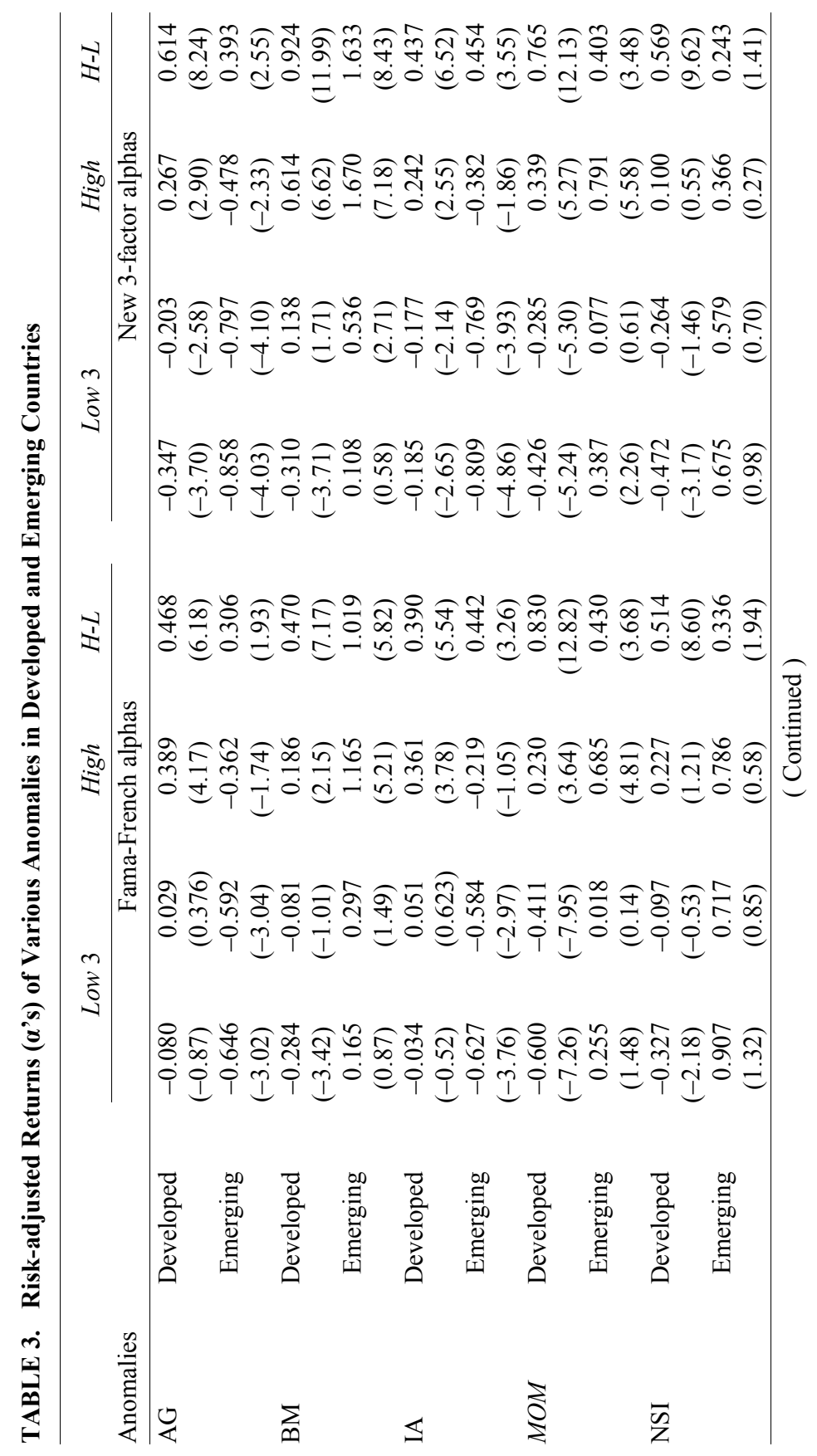




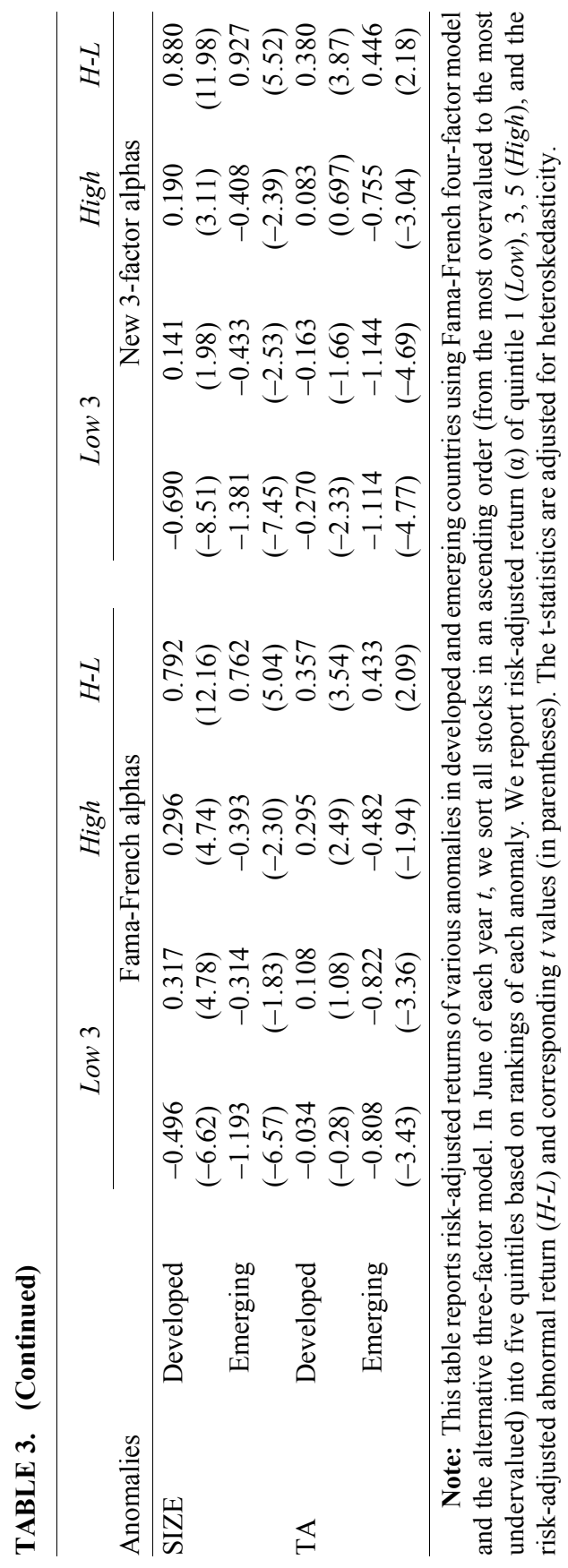




\section{Results}

Our results show abnormal returns obtained from the zero-cost strategy are not explained by Fama-French risk factors. In most countries including the US, abnormal returns remain present after adjusting for Fama-French factors. The alternative three-factor model is re- ported to be able to explain some anomalies in the US equity market. In our study, it can explain some return patterns associated with AG, BM, NSI, and TA, but not $M O M$, IA, and size. However, the additional explanatory power is not observed in countries outside the US. ${ }^{10}$

In addition to examining each individual country, we also conduct risk-adjusted abnormal return analysis for developed and emerging countries. Results are summarized in table 3 . We report $\alpha$ 's for portfolios in the first quintile (Low), the medium quintile (3), and the fifth quintile $(\mathrm{High})$ for each anomaly for both developed and emerging countries. We also report $\alpha$ 's from the zero-cost portfolios $(\mathrm{H}-\mathrm{L})$. As shown in table 3, almost all abnormal returns $(\mathrm{H}-\mathrm{L})$ associated with each anomaly is significant for both developed and emerging countries. Developed countries have higher risk-adjusted abnormal returns for $\mathrm{AG}$, $M O M$, and NSI; emerging countries have higher abnormal returns for $\mathrm{BM}$ and TA; and developed and emerging countries have similar abnormal returns for Size and IA.

Comparing results from the Fama-French and the alternative model, we observe that although these two models have different $\alpha$ 's and $t$-values for the quintile portfolios (i.e. Low, 3, and High), both models produce similar risk-adjusted abnormal returns $(\mathrm{H}-\mathrm{L})$ and significance levels ( $t$-values). The comparisons suggest that the Fama-French and the alternative factor model have similar explanatory power for cross-sectional return patterns in international equity markets. ${ }^{11}$

Our risk-adjusted analyses indicate that holding zero-cost portfolios formed on these anomalies could produce significant abnormal returns

10. The results are available upon request. We do not report them in the paper due to the space limitation.

11. We perform further analyses to make sure our results are not sensitive to portfolio construction methods. We conduct the same analyses using deciles instead of quintiles to group firms and the results are consistent. We also construct 25 size and momentum portfolios (Jegadeesh and Titman, 1993) and run factor regressions using both Fama-French and the alternative model. After controlling for potential size effect, abnormal returns still exist for each size group (except for the small firms in emerging countries) in both models. Due to the space limitation, we do not report results of these analyses. They are available upon request. 
and these abnormal returns cannot be driven away by either the well-established Fama-French risk factors or the new alternative risk factors. The risk-adjusted abnormal returns appear at individual country level, as well as in both developed and emerging countries.

\section{Idiosyncratic Risk and Anomalies}

In this section, we investigate if idiosyncratic risk can explain the existence of the abnormal returns we reported in last section. Identifying reasons that cause anomalies is an extensively studied area in current literature. Studies have suggested that limits of arbitrage, inadequacies of underlying asset-pricing models, missing risk factors, information uncertainty, investors' irrational behaviors, and data snooping could result in an anomaly.

In recent years, in contrast to risk-based explanations, behavioral finance commonly interprets anomalies as evidence of mispricing and market inefficiency. In behavioral finance research, researchers typically examine investment choices of rational and irrational investors. Because of high costs (i.e. limits of arbitrage), rational investors do not fully offset the choices of irrational investors, so mispricing remains. ${ }^{12}$ We hypothesize that abnormal returns associated with these anomalies will be greater among high idiosyncratic risk stocks and smaller among low idiosyncratic risk stocks if idiosyncratic risk does prevent arbitrageurs from offsetting choices of irrational investors.

\section{A. Idiosyncratic risk}

Idiosyncratic risk is measured as the standard deviation of unexpected return innovations. It is usually calculated as the standard deviation of regression residuals from a pricing model (Ang, et al. (2006, 2009). A majority of previous studies use the OLS model to calculate realized idiosyncratic volatility. However, Fu (2009) argues that past realized idiosyncratic volatility should not be an appropriate proxy for expected idiosyncratic risk, because the idiosyncratic volatility of a typical stock does not follow a random walk.

To capture the time-variation of expected idiosyncratic risk, $\mathrm{Fu}$ (2009) proposes an EGARCH model. EGARCH model is also able to

\footnotetext{
12. See Barberis and Thaler (2003) for a comprehensive survey on this topic.
} 
TABLE 4. Summary Statistics of Conditional Idiosyncratic Risk

\begin{tabular}{|c|c|c|c|c|}
\hline Country & $\mathrm{N}$ & Idiovol & STDV & \# of Stocks \\
\hline AUSTRALIA & 249,730 & 0.191 & 0.115 & 788 \\
\hline AUSTRIA & 26,721 & 0.091 & 0.056 & 122 \\
\hline BELGIUM & 33,729 & 0.088 & 0.059 & 144 \\
\hline CANADA & 299,437 & 0.228 & 0.134 & 1201 \\
\hline DENMARK & 56,648 & 0.083 & 0.069 & 251 \\
\hline FINLAND & 28,518 & 0.104 & 0.072 & 158 \\
\hline FRANCE & 220,452 & 0.129 & 0.063 & 1100 \\
\hline GERMANY & 210,331 & 0.123 & 0.069 & 881 \\
\hline GREECE & 57,328 & 0.130 & 0.080 & 303 \\
\hline HONG KONG & 135,628 & 0.160 & 0.112 & 289 \\
\hline IRELAND & 17,335 & 0.114 & 0.095 & 37 \\
\hline ISRAEL & 12,760 & 0.145 & 0.060 & 72 \\
\hline ITALY & 82,389 & 0.094 & 0.066 & 369 \\
\hline JAPAN & 896,204 & 0.126 & 0.051 & 3067 \\
\hline LUXEMBOURG & 4,315 & 0.074 & 0.053 & 25 \\
\hline NETHERLANDS & 58,223 & 0.089 & 0.065 & 258 \\
\hline NEW ZEALAND & 23,606 & 0.118 & 0.059 & 97 \\
\hline NORWAY & 54,852 & 0.107 & 0.064 & 257 \\
\hline PORTUGAL & 24,464 & 0.312 & 0.154 & 116 \\
\hline SINGAPORE & 88,749 & 0.153 & 0.063 & 236 \\
\hline SOUTH KOREA & 196,385 & 0.201 & 0.115 & 509 \\
\hline SPAIN & 35,465 & 0.081 & 0.044 & 178 \\
\hline SWEDEN & 77,742 & 0.137 & 0.069 & 397 \\
\hline SWITZERLAND & 68,533 & 0.085 & 0.058 & 264 \\
\hline TAIWAN & 168,038 & 0.121 & 0.055 & 525 \\
\hline UNITED KINGDOM & 615,414 & 0.085 & 0.075 & 2486 \\
\hline UNITED STATES & $1,807,561$ & 0.143 & 0.119 & 9263 \\
\hline DEVELOPED & $5,550,557$ & 0.130 & 0.095 & 23,391 \\
\hline ARGENTINA & 15,013 & 0.113 & 0.081 & 73 \\
\hline CHILE & 34,498 & 0.090 & 0.036 & 113 \\
\hline CHINA & 175,396 & 0.126 & 0.079 & 798 \\
\hline EGYPT & 6,449 & 0.111 & 0.082 & 50 \\
\hline HUNGARY & 5,163 & 0.173 & 0.104 & 35 \\
\hline INDIA & 148,343 & 0.164 & 0.089 & 384 \\
\hline INDONESIA & 35,900 & 0.248 & 0.183 & 196 \\
\hline MALAYSIA & 151,085 & 0.152 & 0.079 & 216 \\
\hline MEXICO & 19,319 & 0.093 & 0.060 & 112 \\
\hline PAKISTAN & 20,869 & 0.118 & 0.083 & 75 \\
\hline
\end{tabular}


TABLE 4. (Continued)

\begin{tabular}{lrrrr}
\hline Country & \multicolumn{1}{c}{$\mathrm{N}$} & Idiovol & STDV & \# of Stocks \\
\hline PERU & 8,360 & 0.100 & 0.110 & 47 \\
PHILIPPINES & 33,253 & 0.188 & 0.121 & 83 \\
POLAND & 24,224 & 0.145 & 0.088 & 78 \\
SOUTH AFRICA & 96,431 & 0.149 & 0.067 & 405 \\
THAILAND & 88,944 & 0.131 & 0.104 & 402 \\
TURKEY & 40,939 & 0.172 & 0.108 & 123 \\
\hline EMERGING & 904,186 & 0.142 & 0.072 & 3,191 \\
\hline
\end{tabular}

Note: This table reports the means of conditional idiosyncratic risk for each country as well as for developed and emerging countries. Idovol is the one-month-ahead expected idiosyncratic volatility estimated with $\operatorname{EGARCH}(1,1)$ model. $\mathrm{N}$ is firm-month obser- vations. STDV is standard deviation. The total number of stocks in each country is also reported. Sample time period is from 1989 to 2009.

capture asymmetric effects of volatility. We use the following $\operatorname{EGARCH}(p, q)$ to estimate the conditional idiosyncratic volatility of an individual stock's monthly stock return:

$$
\begin{gathered}
R_{i t}=\alpha_{i}+\beta_{0 i} R M_{t}+\beta_{1 i} S M B_{t}+\beta_{2 i} H M L_{t}+\beta_{1 i} M O M_{t}+ \\
\varepsilon_{i t,} \varepsilon_{i t} \sim N\left(0, \sigma_{i t}^{2}\right) \\
\ln \sigma_{i t}^{2}=a_{i}+\sum_{l=1}^{p} b_{i, l} \ln \sigma_{i, t-l}^{2}+\sum_{l=1}^{q} c_{i, k}\left\{\theta\left(\frac{\varepsilon_{i, t-k}}{\sigma_{i, t-k}}\right)+\gamma\left[\left|\frac{\varepsilon_{i, t-k}}{\sigma_{i, t-k}}\right|-(2 / \pi)^{1 / 2}\right]\right\}
\end{gathered}
$$

Monthly return process is described by the Fama-French four-factor model. Model residual $\varepsilon_{i t}$ has a standard normal distribution with mean of zero and variance of $\sigma_{i t}^{2}$, conditional on the information set at time $t-1$. Variance $\sigma_{i t}^{2}$ is a function of the past $p$-period residual variances and $q$-period return shocks, as specified by the second equation.

At the beginning of each month during the holding period, we calculate each stock's conditional idiosyncratic volatility by estimating an EGARCH $(1,1)$ model. ${ }^{13}$ Our sample contains 6,254,358 firm-month observations in 43 countries during our sample time period. Table 4

13. We examine different combinations of $p$ and $q$. The results from $\operatorname{EGARCH}(1,1)$ is representative. 
summarizes the average monthly conditional idiosyncratic risk for each country. We also report standard deviations, the number of firm-month observations, and the number of stocks for each country. Table 4 revealsa wide variation of idiosyncratic risk among countries. Countries with high idiosyncratic risk include Portugal (0.312), Indonesia (0.248), Canada (0.228), and South Korea (0.201). Countries with low idiosyncratic risk are Luxembourg (0.074), Spain (0.081), Denmark (0.083), Switzerland (0.085), and the United Kingdom (0.085). The average idiosyncratic risk for developed countries (0.130) is less than emerging countries (0.142). Miffre et al. (2013) report that idiosyncratic risk is inversely correlated to the number of stocks in portfolios. Their study suggests that the countries with more stocks provide a larger pool of stocks to diversify portfolios; therefore, a country with more stocks would exhibit lower idiosyncratic risk. We do not observe such a correlation in table 4 . We believe the reason is that unlike Miffre et al. (2013) study using US data, our study is conducted internationally. There are many country-level factors that could impact idiosyncratic risk besides the influence of number of stocks.

\section{B. Idiosyncratic risk and individual anomaly}

To examine the relationship between abnormal returns and idiosyncratic risk, we sort stocks into quintiles based on independent rankings on idiosyncratic risk and each anomaly. We then form $5 \times 5$ portfolios using intersections of the five idiosyncratic risk quintiles and five quintiles for each anomaly. We present equal-weighted monthly returns of these 25 portfolios for both developed and emerging countries in table 5. Panels A-G present average monthly returns at different idiosyncraticrisk levels for AG, BM, IA, ME, MOM, NSI, and TA anomaly, respectively. In this table, I1 to I5 represent ranks of idiosyncratic risk from low to high. A1 to A5 stand for the ranks of anomaly. As before, we rank anomalies in such a way that A1 stands for the most undervalued stocks and A5 the most overvalued stocks. The difference between A1 and A5 (A1-A5) is the abnormal return at each idiosyncratic risk level. We report results for both developed and emerging countries.

Table 5 shows a strong positive correlation between abnormal return and idiosyncratic risk. We find stocks with higher idiosyncratic riskalways have higher abnormal return than stocks with lower idiosyncratic risk except for $M O M$ (especially in emerging countries). ${ }^{14}$

14. Some studies suggest that $M O M$ anomaly may not exist in other countries (for example, Fung, Leung, and Patterson, 1999, among others). 
TABLE 5. Monthly Returns of Portfolios formed on the Interactions Between Idiosyncratic Risk and Anomalies

\begin{tabular}{|c|c|c|c|c|c|c|c|}
\hline \multicolumn{8}{|c|}{ A. Interaction with $\mathrm{AG}$} \\
\hline \multicolumn{2}{|l|}{ Economy } & A1 Low & $\mathrm{A} 2$ & A3 & A4 & A5 High & A1-A5 \\
\hline \multirow[t]{10}{*}{ Developed } & \multirow[t]{2}{*}{ I1-Low } & 0.830 & 0.544 & 0.484 & 0.822 & 0.681 & 0.149 \\
\hline & & $(4.38)$ & $(3.76)$ & $(3.92)$ & $(3.67)$ & $(3.376)$ & $(0.59)$ \\
\hline & \multirow[t]{2}{*}{2} & 1.018 & 0.914 & 0.920 & 0.939 & 1.013 & 0.005 \\
\hline & & $(6.26)$ & $(6.85)$ & (7.24) & $(7.44)$ & $(7.398)$ & $(0.03)$ \\
\hline & \multirow[t]{2}{*}{3} & 1.368 & 1.137 & 1.275 & 1.355 & 0.953 & 0.415 \\
\hline & & $(10.53)$ & $(10.05)$ & $(11.34)$ & (11.99) & (7.777) & $(3.23)$ \\
\hline & \multirow[t]{2}{*}{4} & 1.844 & 1.899 & 1.968 & 1.770 & 1.712 & 0.132 \\
\hline & & $(12.57)$ & $(13.86)$ & $(14.08)$ & $(13.33)$ & $(11.252)$ & $(0.90)$ \\
\hline & \multirow[t]{2}{*}{ I5-High } & 4.081 & 3.840 & 3.293 & 3.272 & 3.435 & 0.646 \\
\hline & & $(17.97)$ & $(17.18)$ & $(14.19)$ & $(14.25)$ & (13.397) & $(2.48)$ \\
\hline \multirow[t]{10}{*}{ Emerging } & \multirow[t]{2}{*}{ I1-Low } & 0.755 & 0.628 & 0.728 & 0.814 & 0.869 & -0.114 \\
\hline & & $(2.94)$ & $(2.74)$ & $(2.74)$ & $(2.45)$ & $(3.201)$ & $(-0.38)$ \\
\hline & \multirow[t]{2}{*}{2} & 0.938 & 1.247 & 1.080 & 1.071 & 1.009 & -0.071 \\
\hline & & $(3.54)$ & $(4.63)$ & (4.37) & $(4.15)$ & $(4.113)$ & $(-0.28)$ \\
\hline & \multirow[t]{2}{*}{3} & 0.934 & 1.718 & 1.692 & 1.353 & 1.441 & -0.507 \\
\hline & & $(3.49)$ & $(6.51)$ & $(6.66)$ & $(5.41)$ & $(5.44)$ & $(-1.95)$ \\
\hline & \multirow[t]{2}{*}{4} & 2.352 & 1.845 & 2.333 & 2.416 & 2.276 & 0.077 \\
\hline & & $(6.90)$ & $(6.43)$ & $(7.63)$ & $(7.29)$ & $(7.703)$ & $(0.26)$ \\
\hline & \multirow{2}{*}{ I5-High } & 5.703 & 5.145 & 4.767 & 4.960 & 4.324 & 1.379 \\
\hline & & $(11.43)$ & $(11.11)$ & $(10.47)$ & $(10.87)$ & $(9.655)$ & $(2.71)$ \\
\hline \multicolumn{8}{|c|}{ B. Intersection with BM } \\
\hline \multicolumn{2}{|l|}{ Economy } & A1 Value & $\mathrm{A} 2$ & A3 & A4 & A5 Growth & A1-A5 \\
\hline \multirow[t]{10}{*}{ Developed } & \multirow[t]{2}{*}{ I1-Low } & 0.886 & 0.642 & 0.822 & 0.629 & 0.543 & 0.343 \\
\hline & & $(5.43)$ & $(5.06)$ & $(5.52)$ & $(4.21)$ & $(4.13)$ & $(1.94)$ \\
\hline & \multirow[t]{2}{*}{2} & 0.971 & 0.686 & 0.868 & 0.990 & 0.690 & 0.282 \\
\hline & & $(6.73)$ & $(5.52)$ & $(6.56)$ & $(8.48)$ & $(5.70)$ & (1.94) \\
\hline & \multirow[t]{2}{*}{3} & 1.228 & 1.209 & 1.171 & 1.099 & 0.891 & 0.337 \\
\hline & & $(10.27)$ & $(10.56)$ & $(10.41)$ & $(9.61)$ & (7.55) & $(2.92)$ \\
\hline & \multirow[t]{2}{*}{4} & 2.193 & 2.126 & 1.861 & 1.782 & 1.444 & 0.750 \\
\hline & & $(14.83)$ & $(15.00)$ & (13.80) & (12.89) & (10.08) & $(5.05)$ \\
\hline & \multirow[t]{2}{*}{ I5-High } & 4.113 & 4.007 & 3.440 & 3.215 & 2.695 & 1.418 \\
\hline & & $(17.80)$ & (16.97) & $(15.90)$ & (14.73) & (11.38) & (5.64) \\
\hline \multirow[t]{8}{*}{ Emerging } & \multirow[t]{2}{*}{ I1-Low } & 0.918 & 0.856 & 0.569 & 0.361 & 0.284 & 0.633 \\
\hline & & $(2.72)$ & $(2.81)$ & $(2.52)$ & $(1.48)$ & (1.33) & $(1.85)$ \\
\hline & 2 & 0.977 & 1.153 & 0.825 & 0.961 & 0.802 & 0.175 \\
\hline & & (3.69) & $(4.53)$ & $(3.32)$ & (3.94) & $(3.58)$ & $(0.70)$ \\
\hline & 3 & 1.653 & 1.707 & 1.440 & 1.476 & 0.865 & 0.788 \\
\hline & & $(6.21)$ & $(6.11)$ & $(5.73)$ & $(6.04)$ & (3.89) & $(3.27)$ \\
\hline & 4 & 2.777 & 2.403 & 2.404 & 2.322 & 1.719 & 1.058 \\
\hline & & $(8.55)$ & $(7.89)$ & $(8.28)$ & $(7.85)$ & (6.16) & $(3.4)$ \\
\hline
\end{tabular}


TABLE 5. (Continued)

\begin{tabular}{|c|c|c|c|c|c|c|c|}
\hline \multicolumn{2}{|l|}{ Economy } & A1 Value & $\mathrm{A} 2$ & $\mathrm{~A} 3$ & A4 & A5 Growth & $\mathrm{A} 1-\mathrm{A} 5$ \\
\hline \multirow{2}{*}{\multicolumn{2}{|c|}{ I5-High }} & 5.988 & 5.816 & 4.872 & 4.392 & 4.121 & 1.867 \\
\hline & & $(12.62)$ & $(12.63)$ & $(11.01)$ & $(9.67)$ & $(9.13)$ & $(3.66)$ \\
\hline \multicolumn{8}{|c|}{ C. Intersection with IA } \\
\hline \multicolumn{2}{|l|}{ Economy } & A1 Low & A2 & A3 & A4 & A5 High & A1-A5 \\
\hline \multirow[t]{10}{*}{ Developed } & I1-Low & 0.397 & 1.045 & 0.540 & 0.605 & 0.816 & -0.419 \\
\hline & & (4.67) & $(4.78)$ & $(3.87)$ & $(3.49)$ & $(3.05)$ & $(-1.63)$ \\
\hline & 2 & 0.82 & 1.006 & 1.000 & 0.965 & 1.011 & -0.191 \\
\hline & & (8.10) & $(7.15)$ & $(7.37)$ & (7.04) & (6.99) & $(-1.51)$ \\
\hline & 3 & 1.269 & 1.117 & 1.321 & 1.140 & 1.004 & 0.265 \\
\hline & & $(12.46)$ & $(9.65)$ & $(11.26)$ & $(9.27)$ & $(8.06)$ & $(2.47)$ \\
\hline & 4 & 2.101 & 2.015 & 1.963 & 1.923 & 1.625 & 0.476 \\
\hline & & $(15.17)$ & $(13.70)$ & $(14.24)$ & $(13.14)$ & $(10.42)$ & $(3.58)$ \\
\hline & I5-High & 4.048 & 3.746 & 3.510 & 3.193 & 3.267 & 0.781 \\
\hline & & $(20.11)$ & $(16.01)$ & (14.48) & $(13.60)$ & (13.01) & $(3.45)$ \\
\hline \multirow[t]{10}{*}{ Emerging } & I1-Low & 0.780 & 0.384 & 0.654 & 0.339 & 0.974 & -0.194 \\
\hline & & (3.44) & (1.58) & $(2.57)$ & $(1.35)$ & $(3.41)$ & $(-0.66)$ \\
\hline & 2 & 1.293 & 1.123 & 0.784 & 0.996 & 0.658 & 0.634 \\
\hline & & $(6.12)$ & $(4.48)$ & (2.97) & (4.14) & $(2.65)$ & $(3.25)$ \\
\hline & 3 & 1.588 & 1.514 & 1.101 & 1.437 & 0.944 & 0.644 \\
\hline & & (6.73) & (5.49) & (4.43) & $(5.20)$ & $(3.88)$ & (3.07) \\
\hline & 4 & 2.548 & 2.183 & 2.135 & 2.477 & 1.949 & 0.599 \\
\hline & & (9.59) & (7.06) & (7.09) & $(6.33)$ & (6.67) & $(2.51)$ \\
\hline & I5-High & 6.101 & 5.240 & 5.538 & 4.589 & 3.868 & 2.233 \\
\hline & & $(14.23)$ & (9.94) & $(11.42)$ & $(9.52)$ & $(8.75)$ & (4.91) \\
\hline
\end{tabular}

D. Intersection with Size

\begin{tabular}{|c|c|c|c|c|c|c|c|}
\hline \multicolumn{2}{|l|}{ Economy } & A1 Small & A2 & A3 & A4 & A5 Big & A1-A5 \\
\hline \multirow[t]{10}{*}{ Developed } & I1-Low & 1.121 & 0.882 & 0.678 & 0.554 & 0.525 & 0.596 \\
\hline & & $(12.95)$ & $(12.33)$ & $(10.56)$ & (9.03) & $(8.76)$ & (7.12) \\
\hline & 2 & 1.388 & 1.138 & 0.875 & 0.787 & 0.823 & 0.565 \\
\hline & & (12.03) & $(12.93)$ & (11.7) & $(11.42)$ & $(11.47)$ & $(5.15)$ \\
\hline & 3 & 1.714 & 1.389 & 1.353 & 1.323 & 1.434 & 0.280 \\
\hline & & (14.34) & (13.57) & (14.67) & $(15.70)$ & (16.13) & $(2.40)$ \\
\hline & 4 & 2.360 & 2.064 & 2.106 & 2.103 & 2.007 & 0.352 \\
\hline & & (14.33) & (18.25) & (19.52) & (19.66) & (17.78) & (2.13) \\
\hline & I5-High & 7.190 & 5.108 & 4.452 & 3.922 & 2.786 & 4.403 \\
\hline & & $(32.56)$ & $(30.41)$ & (27.13) & (23.19) & (15.02) & (18.73) \\
\hline \multirow[t]{4}{*}{ Emerging } & I1-Low & 1.627 & 0.954 & 0.701 & 0.872 & 0.390 & 1.237 \\
\hline & & $(6.27)$ & $(4.67)$ & (4.14) & (4.49) & $(2.31)$ & $(4.66)$ \\
\hline & 2 & 1.725 & 1.569 & 1.059 & 1.059 & 1.181 & 0.544 \\
\hline & & $(6.16)$ & $(6.68)$ & $(5.10)$ & $(5.40)$ & $(6.27)$ & (1.98) \\
\hline
\end{tabular}


TABLE 5. (Continued)

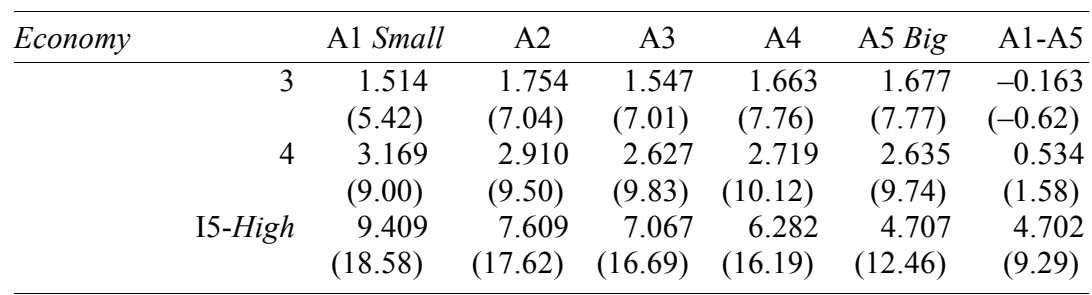

E. Intersection with $M O M$

\begin{tabular}{|c|c|c|c|c|c|c|c|}
\hline Economy & & A1 Winners & $\mathrm{A} 2$ & A3 & A4 & A5 Losers & A1-A5 \\
\hline \multirow[t]{10}{*}{ Developed } & \multirow[t]{2}{*}{ I1-Low } & 0.642 & 0.661 & 0.533 & 0.581 & 1.005 & -0.363 \\
\hline & & $(7.95)$ & (8.24) & (7.79) & (7.67) & (7.68) & $(-2.75)$ \\
\hline & \multirow[t]{2}{*}{2} & 0.996 & 0.909 & 0.858 & 0.907 & 0.891 & 0.105 \\
\hline & & (10.64) & (10.97) & $(10.28)$ & $(10.41)$ & (7.97) & $(0.97)$ \\
\hline & \multirow[t]{2}{*}{3} & 1.361 & 1.382 & 1.098 & 1.202 & 1.346 & 0.015 \\
\hline & & (14.63) & (14.91) & (12.11) & $(12.76)$ & (11.75) & $(0.14)$ \\
\hline & \multirow[t]{2}{*}{4} & 2.172 & 2.052 & 1.682 & 1.812 & 1.925 & 0.247 \\
\hline & & (18.74) & $(17.25)$ & (13.44) & (14.74) & (15.73) & $(2.25)$ \\
\hline & \multirow[t]{2}{*}{ I5-High } & 4.080 & 3.712 & 3.939 & 3.754 & 3.907 & 0.174 \\
\hline & & (22.38) & (18.51) & $(15.44)$ & (18.32) & (22.84) & (0.98) \\
\hline \multirow[t]{10}{*}{ Emerging } & \multirow[t]{2}{*}{ I1-Low } & 0.855 & 0.894 & 0.573 & 0.756 & 0.992 & -0.137 \\
\hline & & (4.10) & $(3.82)$ & (3.14) & $(4.20)$ & (4.09) & $(-0.51)$ \\
\hline & \multirow[t]{2}{*}{2} & 1.197 & 0.961 & 0.941 & 0.895 & 0.841 & 0.355 \\
\hline & & $(6.06)$ & $(4.70)$ & (4.53) & $(4.22)$ & (3.29) & (1.45) \\
\hline & \multirow[t]{2}{*}{3} & 1.554 & 1.410 & 1.315 & 1.516 & 0.928 & 0.626 \\
\hline & & (6.890) & (6.46) & (5.61) & $(6.41)$ & (4.03) & $(2.88)$ \\
\hline & \multirow[t]{2}{*}{4} & 2.758 & 2.686 & 2.347 & 2.511 & 2.253 & 0.505 \\
\hline & & $(10.371)$ & (9.98) & (8.38) & $(8.52)$ & $(7.77)$ & (1.84) \\
\hline & \multirow[t]{2}{*}{ I5-High } & 5.767 & 5.614 & 6.119 & 5.383 & 6.567 & -0.799 \\
\hline & & (14.33) & $(11.75)$ & (12.99) & (11.89) & (15.37) & $(-1.69)$ \\
\hline
\end{tabular}

F. Interaction with NSI

\begin{tabular}{|c|c|c|c|c|c|c|c|}
\hline \multirow{2}{*}{$\frac{\text { Economy }}{\text { Developed }}$} & & A1 Low & A2 & A3 & A4 & A5 High & A1-A5 \\
\hline & I1-Low & $\begin{array}{r}0.843 \\
(5.95)\end{array}$ & $\begin{array}{r}0.782 \\
(3.57)\end{array}$ & $\begin{array}{r}0.305 \\
(1.57)\end{array}$ & $\begin{array}{r}0.563 \\
(3.85)\end{array}$ & $\begin{array}{r}0.527 \\
(3.83)\end{array}$ & $\begin{array}{r}0.316 \\
(1.95)\end{array}$ \\
\hline & \multirow[t]{2}{*}{2} & 1.023 & 0.877 & 0.738 & 0.965 & 0.887 & 0.136 \\
\hline & & (8.63) & $(3.12)$ & $(3.74)$ & (6.85) & $(6.65)$ & $(1.08)$ \\
\hline & \multirow[t]{2}{*}{3} & 1.452 & 1.256 & 1.264 & 1.167 & 1.056 & 0.397 \\
\hline & & (11.63) & $(6.95)$ & $(6.80)$ & (9.67) & (8.73) & $(3.14)$ \\
\hline & \multirow[t]{2}{*}{4} & 2.196 & 2.019 & 1.750 & 1.724 & 1.796 & 0.399 \\
\hline & & (17.17) & $(8.05)$ & (8.24) & (11.18) & (11.40) & $(2.95)$ \\
\hline & \multirow[t]{2}{*}{ I5- High } & 3.949 & 3.817 & 4.174 & 3.374 & 3.457 & 0.492 \\
\hline & & (18.65) & $(9.76)$ & (9.98) & (12.77) & (14.47) & $(2.16)$ \\
\hline \multirow[t]{2}{*}{ Emerging } & \multirow[t]{2}{*}{ I1-Low } & 0.821 & 0.110 & -0.658 & -0.147 & 0.587 & 0.234 \\
\hline & & (3.34) & $(0.10)$ & $(-0.63)$ & $(-0.34)$ & (1.99) & $(0.82)$ \\
\hline
\end{tabular}


TABLE 5. (Continued)

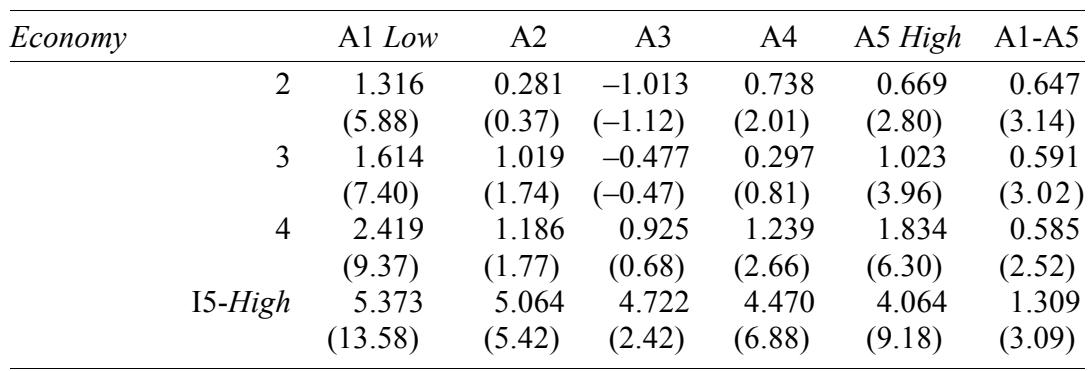

G. Interaction with TA

\begin{tabular}{lccccccc} 
Economy & & A1 Low & \multicolumn{1}{c}{ A2 } & A3 & A4 & A5 High & A1-A5 \\
\hline Developed & I1-Low & 0.824 & 0.619 & 0.514 & 0.733 & 0.671 & 0.153 \\
& & $(4.28)$ & $(3.35)$ & $(1.96)$ & $(3.65)$ & $(3.23)$ & $(0.62)$ \\
& 2 & 0.693 & 0.768 & 0.952 & 0.732 & 0.934 & -0.241 \\
& & $(3.83)$ & $(4.31)$ & $(5.51)$ & $(4.44)$ & $(4.66)$ & $(-1.13)$ \\
& 3 & 1.061 & 1.067 & 1.151 & 1.265 & 0.966 & 0.094 \\
& & $(6.94)$ & $(7.95)$ & $(8.36)$ & $(8.94)$ & $(6.88)$ & $(0.64)$ \\
& & 2.111 & 1.925 & 1.757 & 2.044 & 1.682 & 0.428 \\
& & $(11.91)$ & $(11.72)$ & $(10.95)$ & $(11.97)$ & $(9.50)$ & $(2.56)$ \\
& I5-High & 4.166 & 4.152 & 3.807 & 3.564 & 3.874 & 0.291 \\
& & $(14.78)$ & $(13.13)$ & $(13.49)$ & $(13.2)$ & $(13.21)$ & $(0.96)$ \\
& I1-Low & 0.669 & 0.276 & 0.826 & 0.675 & 0.849 & -0.180 \\
& & $(2.60)$ & $(1.01)$ & $(2.11)$ & $(2.18)$ & $(2.63)$ & $(-0.52)$ \\
& 2 & 0.997 & 0.811 & 1.068 & 0.779 & 0.764 & 0.233 \\
& & $(3.66)$ & $(3.07)$ & $(3.61)$ & $(2.76)$ & $(2.78)$ & $(0.87)$ \\
& 3 & 1.015 & 1.568 & 1.311 & 1.599 & 0.982 & 0.033 \\
& & $(3.61)$ & $(5.63)$ & $(4.68)$ & $(5.60)$ & $(3.48)$ & $(0.12)$ \\
& 4 & 2.430 & 2.171 & 2.604 & 2.114 & 2.078 & 0.352 \\
& & $(7.30)$ & $(6.80)$ & $(7.24)$ & $(6.73)$ & $(5.19)$ & $(0.91)$ \\
& I5-High & 4.971 & 5.122 & 5.173 & 4.284 & 4.530 & 0.441 \\
& & $(9.01)$ & $(9.53)$ & $(9.59)$ & $(8.14)$ & $(8.79)$ & $(0.76)$ \\
\hline
\end{tabular}

Note: Panels A to G present monthly returns of portfolios formed on intersections between idiosyncratic risk and equity anomalies including AG, BM, IA, MOM, NSI, Size, and TA. Idiovol is the estimated monthly expected idiosyncratic volatility from $\operatorname{EGARCH}(1,1)$. Newey-West t-statistics are reported in parenthesis. I1 to I5 represent the rank of idiosyncratic risk from low to high. A1 to A5 stand for the rank of anomaly. We rank anomalies in such a way that A1 stands for the most undervalued stocks (such as stocks with low AG, small size, etc.) and A5 the most overvalued stocks (such as stocks with high AG, big size, etc.). The difference between A1 and A5 (A1-A5) is the abnormal return for each idiosyncratic risk level.

For instance, for anomaly AG (Panel A), stocks with the highest idiosyncratic risk in developed countries have an abnormal $r$ eturns of $0.646 \%$ compared to an abnormal return of $0.149 \%$ for stocks with the 
lowest idiosyncratic risk. This pattern is persistent in both developed and emerging countries.

We also find that abnormal returns for stocks with low idiosyncratic risk are usually either not significantly different from zero at 5\% level (anomaly AG, IA, NSI, and TA), or the documented return pattern is not evident (anomaly $M O M$ ). On the other hand, most of the abnormal returns for stocks with high idiosyncratic risk are significant at $5 \%$ level. It is consistent with the limits of arbitrage theory, because risk-averse arbitrageurs are more likely to eliminate abnormal returns for stocks with low idiosyncratic risk at a lower cost, but they fail to do so for stocks with high idiosyncratic risk due to a higher cost.

\section{Regression analysis}

In this section, we perform regression analysis to further explore the mispricing explanation. We test three hypotheses based on the mispricing explanation: 1) idiosyncratic risk and abnormal return are positively correlated at portfolio level (zero-cost portfolio), 2) developed countries have lower abnormal returns, and 3) the same level of idiosyncratic risk has lower impact on abnormal return in developed countries compared to emerging countries. We use the risk-adjusted monthly abnormal return from the Fama-French model as the dependent variable. More specifically, we regress abnormal returns of zero-cost portfolios on size, value, and momentum factors. The intercept (i.e. $\alpha$ ) is defined as the risk-adjusted monthly abnormal return. Idiosyncratic risk and a number of country-level characteristics are used as independent variables. Since abnormal returns are computed as the monthly $\alpha$ 's of zero-cost portfolios (longing most undervalued stocks and shorting most overvalued stocks), we define idiosyncratic risk of a zero-cost portfolio as the value-weighted average of the idiosyncratic risk of stocks with long-position minus the value-weighted average of the idiosyncratic risk of stocks with short-position in the zero-cost portfolio. We apply the following model to each anomaly:

$$
\begin{aligned}
\mathrm{AR}_{j t}= & \alpha_{0}+\beta_{1} \text { Idovol }_{-} P_{j t}+\beta_{2} \text { Economy }+\beta_{3} \text { Economy }^{*} \text { Idovol }_{-} P_{j t}+ \\
& F_{j} \gamma_{1}+\mathrm{A}_{j y} \gamma_{2}+M_{j t} \gamma_{3}+\varepsilon_{i, t}
\end{aligned}
$$

where $\mathrm{A} R_{j t}$ is the risk-adjusted abnormal return ( $\alpha$ from the Fama-French model) in country $j$ and in month $t$. Idovol_ $P_{j t}$ is the idiosyncratic risk of a zero-cost portfolio in country $j$ and in month $\mathrm{t}$. 
Economy is a dummy variable ( 1 for developed countries and 0 for emerging countries). While $F_{j}$ is a vector of country characteristics that are constant over time, $\mathrm{A}_{j y}$ and $M_{j t}$ are vectors of country characteristics that are updated annually and monthly, respectively. $\varepsilon_{i t}$ is an error term. appendix A provides details on these country variables.

We use panel regression analysis with standard errors clustered by country and year (Petersen, 2009) table 6 reports parameter estimates, $t$ values, and R squares. We test three models for each anomaly. Model 1 (M1) is the base model that examines the positive correlation between idiosyncratic risk and abnormal return. Model 2 (M2) tests if abnormal return is different between developed and emerging countries using the dummy variable Economy. Model 3 (M3) tests if idiosyncratic risk has a different impact on abnormal returns between developed and emerging countries using the interaction term $\left(\right.$ Economy*Idovol_ $\left.P_{j t}\right)$. Under mispricing hypothesis, we expect to have a positive $\beta 1$ and negative $\beta 2$ and $\beta 3$.

There are several interesting observations in table 6. First, we observe a strong positive correlation between abnormal return and idiosyncratic risk for each anomaly using different models. The positive impact of idiosyncratic risk on abnormal return is consistent with findings from the previous section. It not only confirms that idiosyncratic risk is an important factor attributing to the existence of anomalies, but also shows that the effect is persistent across countries and over time. In addition, this positive correlation still remains significant after we control for various country characteristics.

Second, we find that the dummy variable Economy has a negative coefficient for BM, IA, $M O M$, NSI, SIZE, and TA, although only size is significant at $5 \%$ level in all models. Anomaly AG has positive but insignificant coefficient. We do not observe significant effects of country level characteristics on most anomalies (expect for $M O M$ ) either. Although the mispricing theory suggests country characteristics (such as governance quality, investor protection, and accounting standards) would have a negative impact on abnormal returns, our results do not provide strong evidence to support it. However, it is possible that the impact of country characteristics is already captured by other factors in our model, such as the idiosyncratic risk.

Finally, table 6 presents evidence that the same level of idiosyncratic risk produces lower abnormal return in developed countries. The coefficients of the interaction term Economy*Idovol_ $P_{j t}$ are negative for all anomalies. These negative coefficients are significant at the $5 \%$ level for $\mathrm{AG}$, IA, and size, and 10\% for MOM. Developed countries in general have better governance and stronger investor protection that 


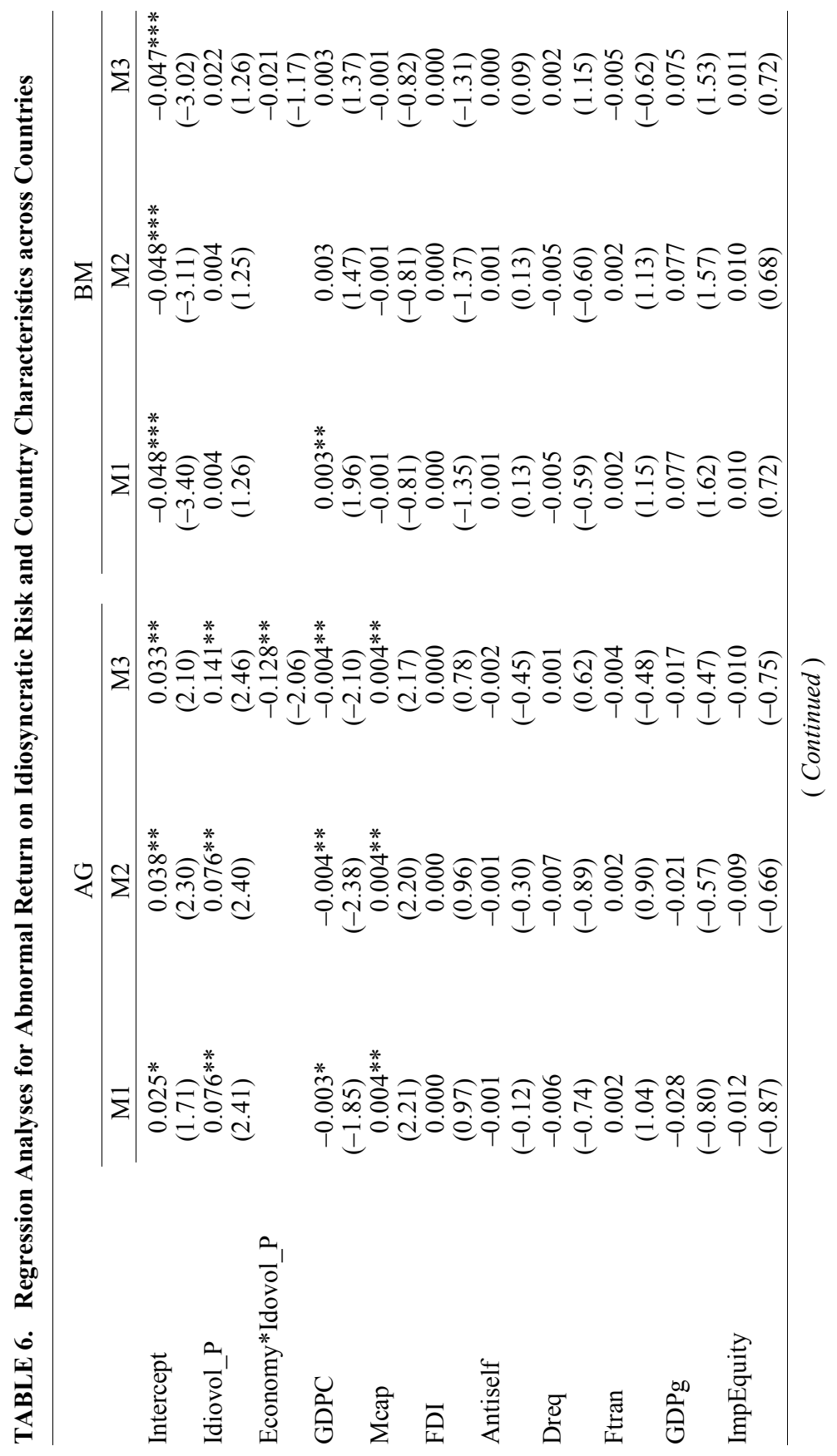




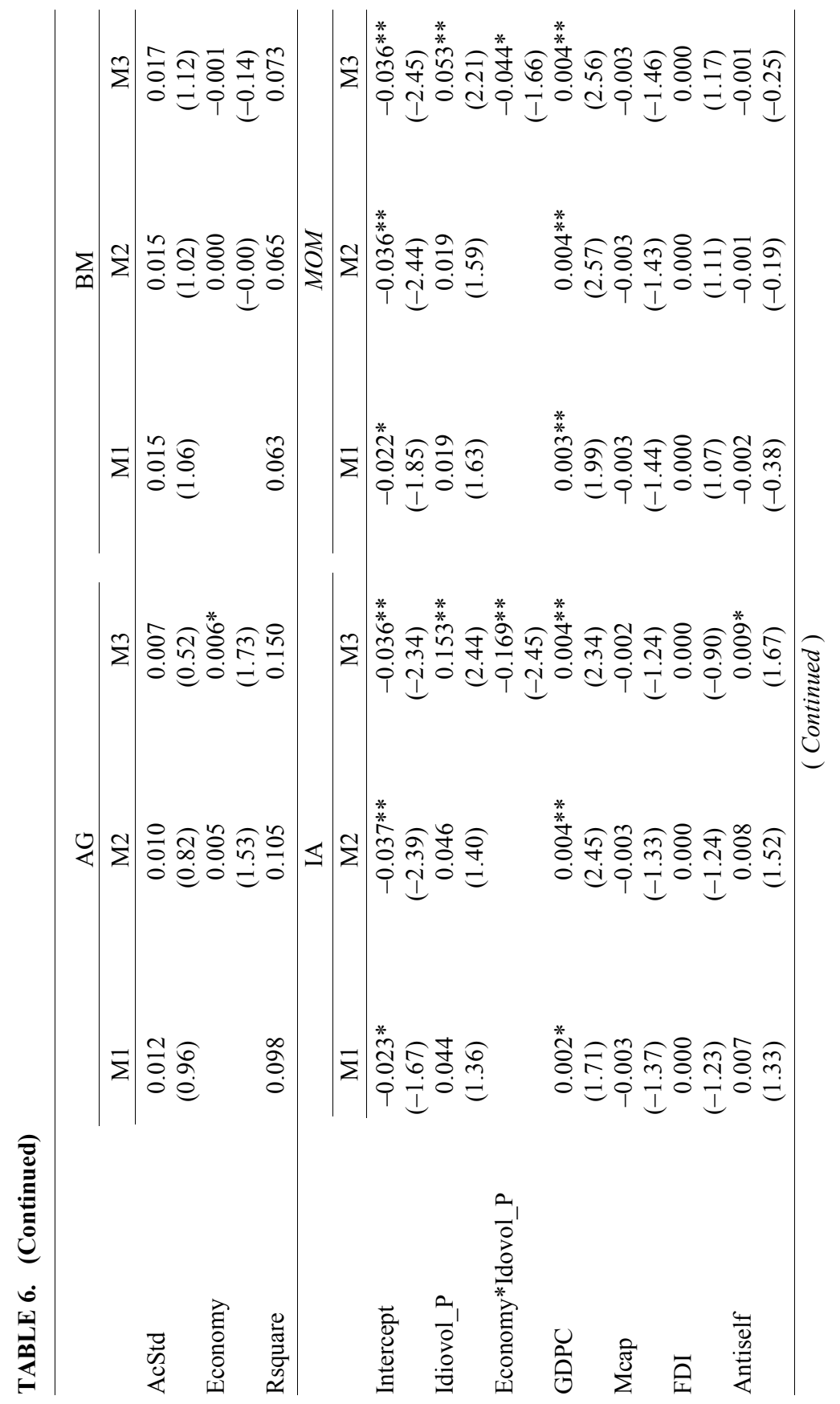




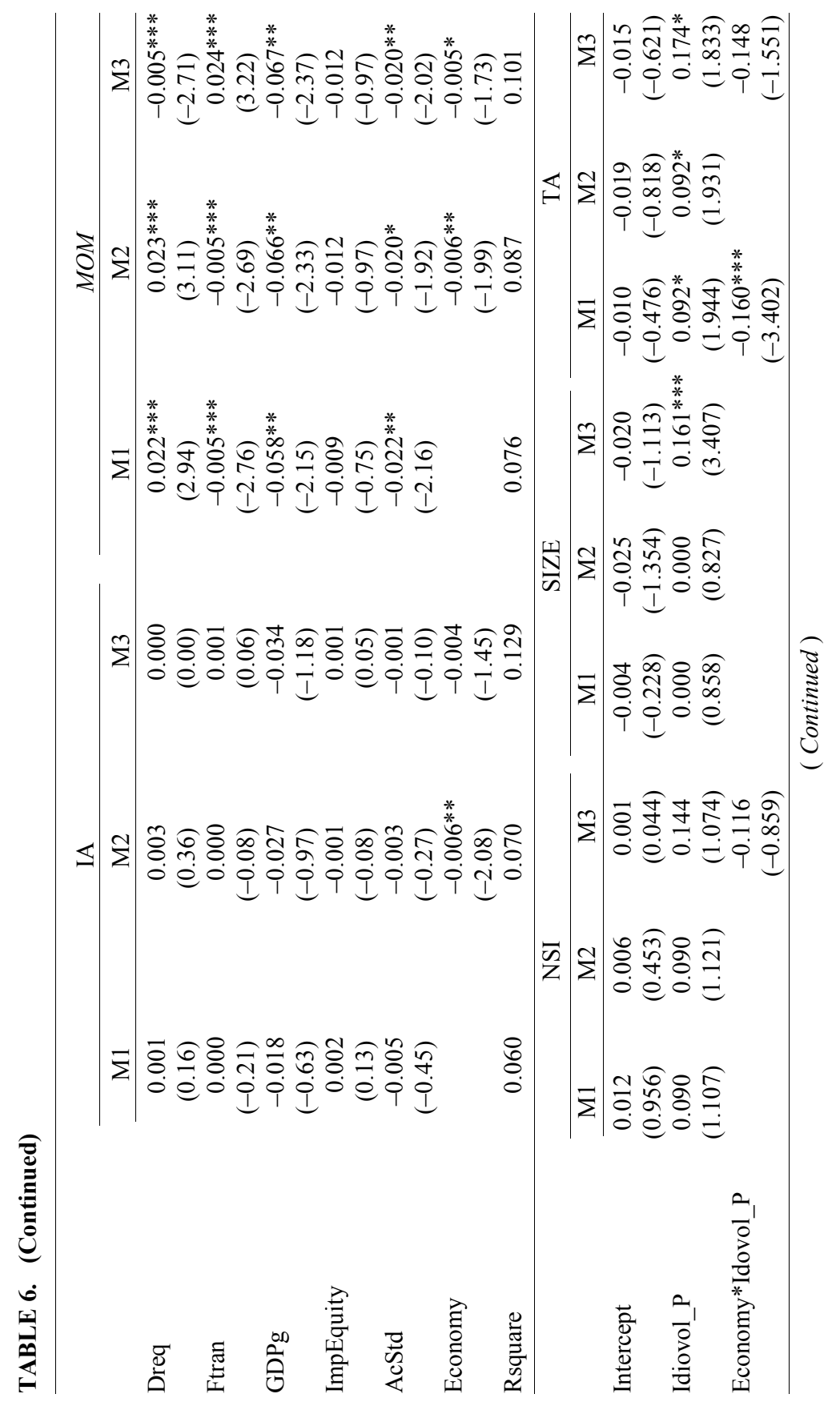




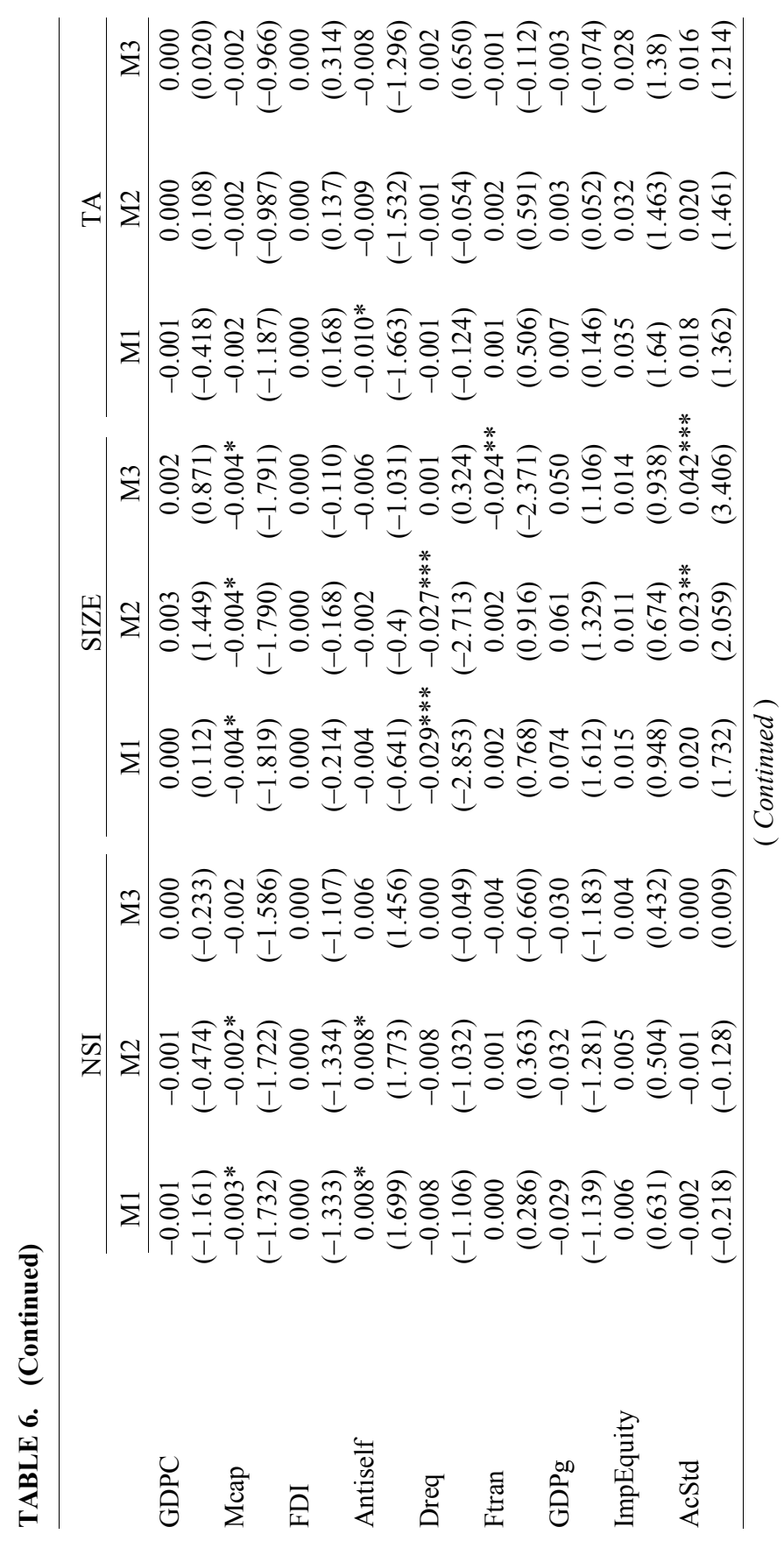




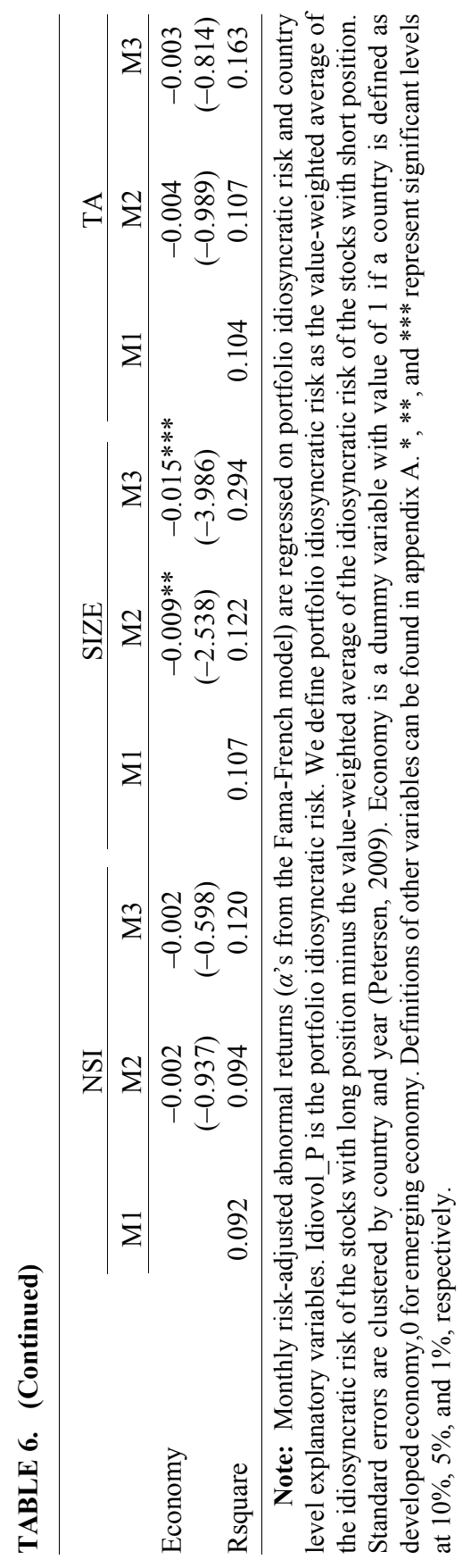


allow rational investors to drive away arbitrage opportunities at lower cost and take more aggressive positions to offset mispricing. Our results support this hypothesis.

Overall, we find idiosyncratic risk is an important factor contributing to the existence of the studied anomalies. It has significant impacts on abnormal returns; its impact is different between developed and emerging countries. Our main results support the mispricing theory.

\section{Conclution}

In this study, we investigate a wide array of anomaly variables in capital markets around the world, including asset growth, book-to-market, investment-to-assets, momentum, net stock issues, size, and total accruals. We use zero-cost trading strategy, the Fama-French factor model, and the newly developed alternative investment-based three-factor model to show that these anomalies produce significant abnormal returns across countries, and there are significant variations among countries and between developed and emerging economies. We acknowledge that there is a large volume of equity anomaly studies in the literature. Our study only covers a small spectrum of it. For instance, we are not trying to identify if an anomaly is persistent over time nor how abnormal returns are influenced by other factors, such as transaction costs, etc.

We examine if these anomalies can be explained by idiosyncratic risk. Using a portfolio approach, we document a strong positive correlation between abnormal return and idiosyncratic risk. These results provide strong evidence to support the limits of arbitrage theory across countries. Using cross-country regression analysis, we also document a positive correlation between idiosyncratic risk and abnormal return after controlling for country characteristics. It suggests that existence of the anomalies is due to idiosyncratic risk. Moreover, the impact of idiosyncratic risk on abnormal return in developed countries is significantly weaker than the impact on abnormal return in emerging countries. Our results support the mispricing explanation of the existence of various anomalies around the world.

Accepted by: P.C. Andreou, PhD, Editor-in-Chief(Pro-Tem), October 2014 


\section{Appendix A. Country-level Variables}

\begin{tabular}{lll} 
Variables & Acronym & Description and source of information \\
\hline (i) Economic and Financial Development & GDPC & $\begin{array}{l}\text { Log of per capita GDP measured in } \\
\text { GDP per capita }\end{array}$ \\
& $\begin{array}{l}\text { US dollar in year } t \text { - } 1 \text { (World } \\
\text { Development Indicators (WDI)). }\end{array}$
\end{tabular}

Stock market cap to GDP Mcap Ratio of stock market capitalization to GDP in year $t-1$ (WDI).

Importance of equity market ImpEquity The mean ranking of a country across three variables (ratio of aggregate stock market capitalization held by minorities to GNP, number of listed domestic firms relative to the population, and number of IPOs relative to the population) with higher scores indicating greater importance of the stock market ( $\mathrm{La}$ Porta et al. 1997).

Developed/Emerging Economies Economy World Bank's classification scheme (2005).

(ii) Economic Growth

GDP growth GDP

Annual GDP growth in year $t-1$ (WDI).

(iii) Economic and Financial Integration

FDI to GDP FDI

(iv) Financial Disclosure Environment

Financial transparency factor Ftran

Measure of intensity and timeliness of financial disclosures by firms, and interpretation and dissemination of firms' news (Bushman et al., 2004).

Accounting standard index

AcStd

Ratio of the sum of absolute values of FDI inflows and outflows with US to GDP in year $t-1$ (WDI).

It examines and rates companies' 1990 annual reports on 90 items for 36 countries, covering general information, income statements, balance sheets, fund flow statements, accounting standards, and general information, income statements, balance sheets, fund flow statements, accounting standards, and stock data (La Porta et al., 1998). 


\begin{tabular}{|c|c|c|}
\hline Variables & Acronym & Description and source of information \\
\hline Disclosure requirements index & Dreq & $\begin{array}{l}\text { The average score of six } \\
\text { sub-indexes: prospectus delivering, } \\
\text { insider compensations, large } \\
\text { shareholder ownership, insider } \\
\text { ownership, contracts outside the } \\
\text { normal course of business, and } \\
\text { related parties transactions. All these } \\
\text { sub-indexes are dummy variables. } \\
\text { For each sub-index, } 1 \text { represents } \\
\text { significantly high value in that } \\
\text { category, } 0 \text { otherwise (La Porta et } \\
\text { al., 2006). }\end{array}$ \\
\hline \multicolumn{3}{|c|}{ (v) Corporate Governance Environment } \\
\hline Antiself dealing index & $\begin{array}{l}\text { Antiself dealing } \\
\text { index }\end{array}$ & $\begin{array}{l}\text { It focuses on a country's disclosure } \\
\text { quality, approval, and litigation } \\
\text { governing self-dealing transactions } \\
\text { (Djankov et al., 2008) }\end{array}$ \\
\hline
\end{tabular}

\section{References}

Ali, A.; Hwang, L. S.; and Trombley, M. A. 2003. Arbitrage risk and the book-to-market anomaly. Journal of Financial Economics 69: 355-373.

Ammann M.; Odoni, S.; and Oesch, D.; 2012. An alternative three-factor model for inter- national markets: Evidence from the European Monetary Union. Journal of Banking and Finance 36: 1857-1864.

Ang, A.; Hodrick, R.; Xing, Y.; and Zhang, X. 2006. The cross-section of volatility and expected returns. Journal of Finance 61: 259-299.

Ang, A.; Hodrick, R.; Xing, Y.; and Zhang, X. 2009. High idiosyncratic volatility and low returns: International and further U.S. evidence. Journal of Financial Economics 91: 1-23.

Bali, T. G.; Cakici N.; Yan X.; and Zhang, Z. 2005. Does idiosyncratic risk really matter? Journal of Finance 60: 905-929.

Banz, R. 1981. The relationship between return and market value of common stocks. Journal of Financial Economics 9: 3-18.

Barberis, N., and Thaler, R. 2003. A survey of behavioral finance. In G. M. Constantinides, M. Harris, and R. M. Stulz (eds.) Handbook of the economics of finance, Vol. 1A. North-Holland, Amsterdam.

Chen, J. 2002. Intertemporal, CAPM and the cross-section of stock returns. Working paper, University of Southern California.

Carhart, M. 1997. On persistence in mutual fund performance. Journal of Finance 52: 57-82. 
Chen, L.; Novy-Marx, R.; and Zhang, L. 2010. An Alternative Three-Factor Model. Working Paper, SSRN.

Cooper, M.; Gulen, H.; and Schill, M. 2008. Asset growth and the cross-section of stock returns. Journal of Finance 63: 1609-1651.

Daniel, K.; Hirshleifer, D.; and Subrahmanyam, A. 1998. Investor psychology and security market under- and overreaction. Journal of Finance 53: 1839-1885.

DeMoor, L., and Sercu, P. 2005. CAPM tests and alternative factor portfolio composition: getting the alphas right. Working paper, SSRN.

Diavatopoulos, D.; Doran J. S.; and Peterson D. R. 2008. The information content in implied idiosyncratic volatility and the cross-section of stock returns: Evidence from the option markets. Journal of Futures Markets 28: 1013-1039.

Djankov, S.; La Porta, R.; Lopez-de-Silanes, F.; and Shleifer, A. 2008. The law and economics of self-dealing. Journal of Financial Economics 88: 430-465.

Errunza, V., and Losq, E. 1985. International asset pricing under mild segmentation: Theory and tests. Journal of Finance 40, 105-124.

Fama, E., and French, K. 1992. The cross-section of expected stock returns. Journal of Finance 42: 427-465.

Fama, E., and French, K. 1993. Common risk factors in the returns on stocks and bonds. Journal of Financial Economics 33: 3-56.

Fama, E., and French, K. 2008. Dissecting anomalies. Journal of Finance 63: 1653-1678.

Fan, Z., and Yu, L. 2013. Accrual Anomaly and Idiosyncratic Risk. The International Journal of Business and Finance Research 7, 63-75.

Fu, F. 2009. Idiosyncratic risk and the cross-section of expected stock returns. Journal of Financial Economics 91: 24-37.

Fung, H.; Leung, W.; and Patterson, G. 1999. Do trading rules based upon winners and losers work across markets? Evidence from the Pacific Basin and U.S. Markets. Multinational Finance Journal 3: 41-70.

Goyal, A., and Santa-Clara P. 2003. Idiosyncratic risk matters! Journal of Finance 58: 975-1007.

Griffin, J. 2002. Are the Fama and French factors global or country specific? Review of Financial Studies 15: 783-803.

Griffin, J.; Kelly, P.; and Nardari, F. 2010. Do market efficiency measures yield correct inferences? A comparison of developed and emerging markets. Review of Financial Studies 23: 3225-3277.

Griffin J., and Lemmon, M. 2002. Does book-to-market equity proxy for distress risk? Journal of Finance 57: 2317-2336.

Guo, H., and Savickas R. 2010. Relation between time-series and cross-sectional effects of idiosyncratic variance on stock returns. Journal of Banking and Finance 34: 1637-1649.

Heston, S. L.; Rouwenhorst, K. G.; and Wessels, R. E. 1995. The structure of 
international stock returns and the integration of capital markets. Journal of Empirical Finance 2: 173-197.

Hober, G., and Welch, I. 2009. Optimized vs. sort-based portfolio. Working Paper, University of Maryland.

Hou, K.; Karolyi, G.A.; and Kho, B. 2011. What factors drive global stock returns? Review of Financial Studies 24: 2527-2574.

Huang, W.; Liu Q.; Rhee S. G.; and Zhang L. 2010. Return reversals, idiosyncratic risk and expected returns. Review of Financial Studies 23: 147-168.

Ince, O., and Porter R. 2006. Individual equity return data from Thomson Datastream: Handle with care. Journal of Financial Research 29: 463-479.

Jegadeesh, N., and Titman, S. 1993. Returns to buying winners and selling losers: Implications for stock market efficiency. Journal of Finance 48: 65-91.

Karolyi, A.; Lee K.; and Van Dirk M. 2012. Understanding commonality in liquidity around the world. Journal of Financial Economics 105: 82-112.

Karolyi, G. A., and Stulz, R. 2003. Are financial assets priced locally or globally? In G. M. Constantinides, M. Harris, and R. M. Stulz (eds.) Handbook of the economics of finance, Vol. 1B. North-Holland, Amsterdam.

La Porta, R.; Lopez-de-Silanes, F.; Shleifer, A.; and Vishny, R. W. 1997. Legal determinants of external finance. Journal of Finance 52: 1131-1150.

La Porta, R.; Lopez-de-Silanes, F.; Shleifer, A.; and Vishny, R. W. 1998. Law and finance. Journal of Political Economy 106: 1113-1155.

La Porta, R.; Lopez-de-Silanes, F.; Shleifer, A.; and Vishny, R. W. 2006. What works in securities laws? Journal of Finance 61: 1-32.

Lintner, J. 1965. The valuation of risk assets and the selection of risky investments in stock portfolios and capital budgets. Review of Economics and Statistics 47: 13-37.

Lipson, M. L.; Mortal, S.; and Schill, M. J. 2012. On the scope and drivers of the asset growth effect. Journal of Financial and Quantitative Analysis 46: 1651-1682.

Lyandres, E.; Sun, L.; and Zhang, L. 2008. The new issues puzzle: Testing the investment- based explanation. Review of Financial Studies 21: 2825-2855.

Malkiel, B.G., and Xu, Y. 2006. Idiosyncratic risk and security returns. Working paper, SSRN.

Mashruwala, C.; Rajgopal, S.; and Shevlin, T. 2006. Why is the accrual anomaly not arbitraged away? The role of idiosyncratic risk and transaction costs. Journal of Accounting and Economics 42: 3-33.

Mendenhall, R. 2004. Arbitrage risk and post-earnings-announcement drift. Journal of Business 77: 875-894.

Merton, R. 1973. An intertemporal capital asset pricing model. Econometrica 41: 867-887.

Miffre, J.; Brooks, C.; and Li, X. 2013. Idiosyncratic volatility and the pricing 
of poorly diversified portfolios. International Review of Financial Analysis 30: 7885.

Pastor, L., and Stambaugh, R. F. 2003. Liquidity risk and expected stock returns. Journal of Political Economy 111: 642-685.

Petersen, M. 2009. Estimating standard errors in finance panel data sets: Comparing Approaches. Review of Financial Studies 22: 435-480.

Pincus, M.; Rajgopal, S.; and Venkatachalam, M. 2007. The accrual anomaly: International evidence. The Accounting Review 82: 169-203.

Pontiff, J. 1996. Costly arbitrage: Evidence from closed-end funds. The Quarterly Journal of Economics 111: 1135-1151.

Pontiff, J. 2006. Costly arbitrage and the myth of idiosyncratic risk. Journal of Accounting and Economics 42: 35-52.

Richardson, S.; Tuna, I.; and Wysocki, P. 2010. Accounting anomalies and fundamental analysis: A review of recent research advances. Journal of Accounting and Economics 50: 410-454.

Ross, S. 1976. The arbitrage theory of capital asset pricing. Journal of Economic Theory 13: 341-360.

Schwert, G. W. 2003. Anomalies and market efficiency. In G. M. Constantinides, M. Harris, and R. M. Stulz (eds.) Handbook of the economics of finance, Vol. 1B. North-Holland, Amsterdam.

Sharpe, W. 1964. Capital asset prices: A theory of market equilibrium under conditions of risk. Journal of Finance 19: 425-442.

Shleifer, A., and Vishny, R. 1997. The limits of arbitrage. Journal of Finance 52: 35-55.

Sloan, R. 1996. Do stock prices fully reflect information in accruals and cash flows about future earnings? The Accounting Review 71: 289-315.

Tang, Y.; Wu, J.; and Zhang, L. 2013. Do anomalies exist Ex Ante? Review of Finance 18: 843-875.

Walkshausl, C., and Lobe, S. 2011. The alternative three-factor model: An alternative beyond US markets? European Financial Management 17: 1-38. 